\title{
CHAPTER A: BEDROCK GEOLOGIC MAP OF THE LADUE RIVER-MOUNT FAIRPLAY AREA, TANACROSS AND NABESNA QUADRANGLES, ALASKA
}

Evan Twelker ${ }^{1}$, Rainer J. Newberry ${ }^{2}$, Alicja Wypych ${ }^{1}$, Travis J. Naibert ${ }^{1}$, Alec D. Wildland ${ }^{1}$, Karri R. Sicard ${ }^{1}$, Sean P. Regan ${ }^{2}$, Jennifer E. Athey ${ }^{1}$, W. Chris Wyatt ${ }^{1}$, and Julian A. Lopez ${ }^{3}$

\section{INTRODUCTION}

The Mineral Resources section of the Alaska Division of Geological \& Geophysical Surveys (DGGS) conducted bedrock geologic mapping of a 4,800-sq-km (1,860-sq-mi) area of eastern Interior Alaska including Mount Fairplay and the Ladue River drainage. The area lies north of the Alaska
Highway and is approximately $65 \mathrm{~km}$ (40 mi) east of Tok, Alaska; it runs west from the Alaska-Yukon border to encompass the Taylor Highway (fig. 1). DGGS and the U.S. Geological Survey (USGS) staff identified this area as having potential to host deposits of critical minerals, including rare earth elements (REE), uranium, niobium, zirconium,

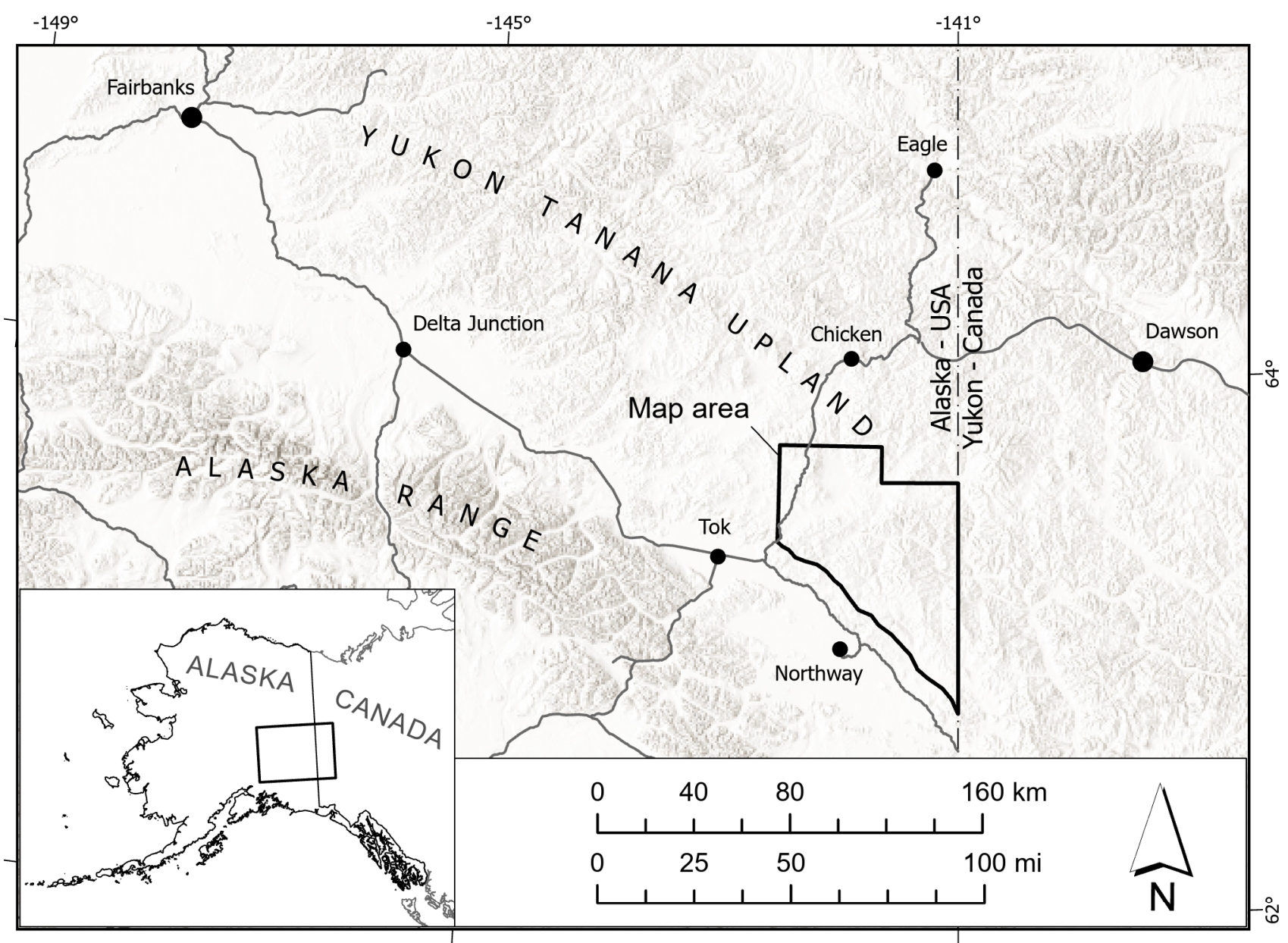

Figure 1. Map showing the geographic location of the map area.

\footnotetext{
${ }^{1}$ Alaska Division of Geological \& Geophysical Surveys, 3354 College Rd., Fairbanks, Alaska 99709-3707

2 Department of Geosciences, University of Alaska, P.O. Box 755780, Fairbanks, Alaska 99775-5780

${ }^{3}$ Colorado College, Department of Geology, 14 East Cache la Poudre St., Colorado Springs, CO 80903
} 
tin, tungsten, bismuth, and rhenium, as well as conventional mineral resources including gold, copper, molybdenum, lead, zinc, and silver. Most of the known mineralization in the area is related to Cretaceous-Paleogene magmatism, which spans a broad diversity of compositions and ranges in scale from batholiths to shallowly emplaced dikes to volcanic rocks. The igneous rocks intrude a composite metamorphic province that includes both parautochthonous North America and components of the allochthonous Yukon Tanana Terrane, now juxtaposed against one another by Jurassic-Cretaceous low-angle faults and subsequently disrupted by multiple generations of Cretaceous-Cenozoic high-angle faults (fig. 2).

This map and associated geologic report are the product of 315 person-days of helicopter-supported fieldwork completed by the authors during 2019, plus limited compilation of existing geologic maps of the area (Foster, 1967; Foster, 1970). The age assignments for igneous and metaigneous map units are supported by 37 new U-Pb zircon ages completed as part of this study (table 1; Wildland and others, 2021). Cooling ages of metamorphic rocks and hydrothermal alteration assemblages are informed by preliminary results from 24 new ${ }^{40} \mathrm{Ar} /{ }^{39} \mathrm{Ar}$ ages, which are in-process. Several detrital zircon analyses contributed to our understanding of the Cretaceous sedimentary rocks (table 2; Twelker and O'Sullivan, 2021b). All age uncertainties in this report are $2 \sigma$ (95 percent confidence level), and where original data sources reported $1 \sigma$ uncertainty we have converted it to $2 \sigma$. We used geochemical data, including 284 whole-rock analyses (Wypych and others, 2019) and more than 1,600 handheld X-ray fluorescence (XRF) analyses, to describe, classify, and map the distribution of different lithologic units on the map. In addition to our own data, this map is also built on an open exchange of data and ideas with our colleagues at the U.S. Geological Survey Alaska Science center, including zircon ages (Jones and O'Sullivan, 2020) and ${ }^{40} \mathrm{Ar} /{ }^{39} \mathrm{Ar}$ ages (Jones and Benowitz, 2020).
The map area lies in the Yukon-Tanana Upland (Wahrhaftig, 1960) and is characterized by moderate-relief, thickly vegetated hills and minimal outcrop; glacial deposits were not observed and eolian deposits are generally thin. Our map interpretation relies on observations of outcrop, subcrop, and float, and we make extensive use of airborne magnetic (Emond and others, 2015) and magnetic-electromagnetic surveys (Burns and others, 2020a,b) for interpolation between field stations. Our mapping of high-angle faults relies on tilt-derivative processing of aeromagnetic data, low resistivity anomalies in electromagnetic surveys, photo and topographic lineaments, and lithologic discontinuities between ridges.

This report includes the following chapters emphasizing different aspects of the geology of the study area:

- Chapter A: Introduction and description of map units

- Chapter B: Metamorphism of the Ladue River-Mount Fairplay area

- Chapter C: Regional correlation of metamorphic rocks in the Ladue River-Mount Fairplay map area using trace-element geochemistry

- Chapter D: Structural geology of the Mount Fairplay-Ladue River area

- Chapter E: Geochemistry of select igneous rocks of the Ladue River-Mount Fairplay area

- Chapter F: Economic geology of the Ladue River-Mount Fairplay area

\section{REGIONAL GEOLOGY}

The Ladue River-Mount Fairplay map area includes the structurally complex boundary between the allochthonous Yukon Tanana Terrane (YTT) and the parautochthonous North American margin (pNA; fig. 2). The YTT includes a series of late Paleozoic volcanic arcs and related intrusive rocks on basement rifted from the western margin of North America (Laurentia) during the Late Devonian-Early Mississippian (Dusel-Bacon and 


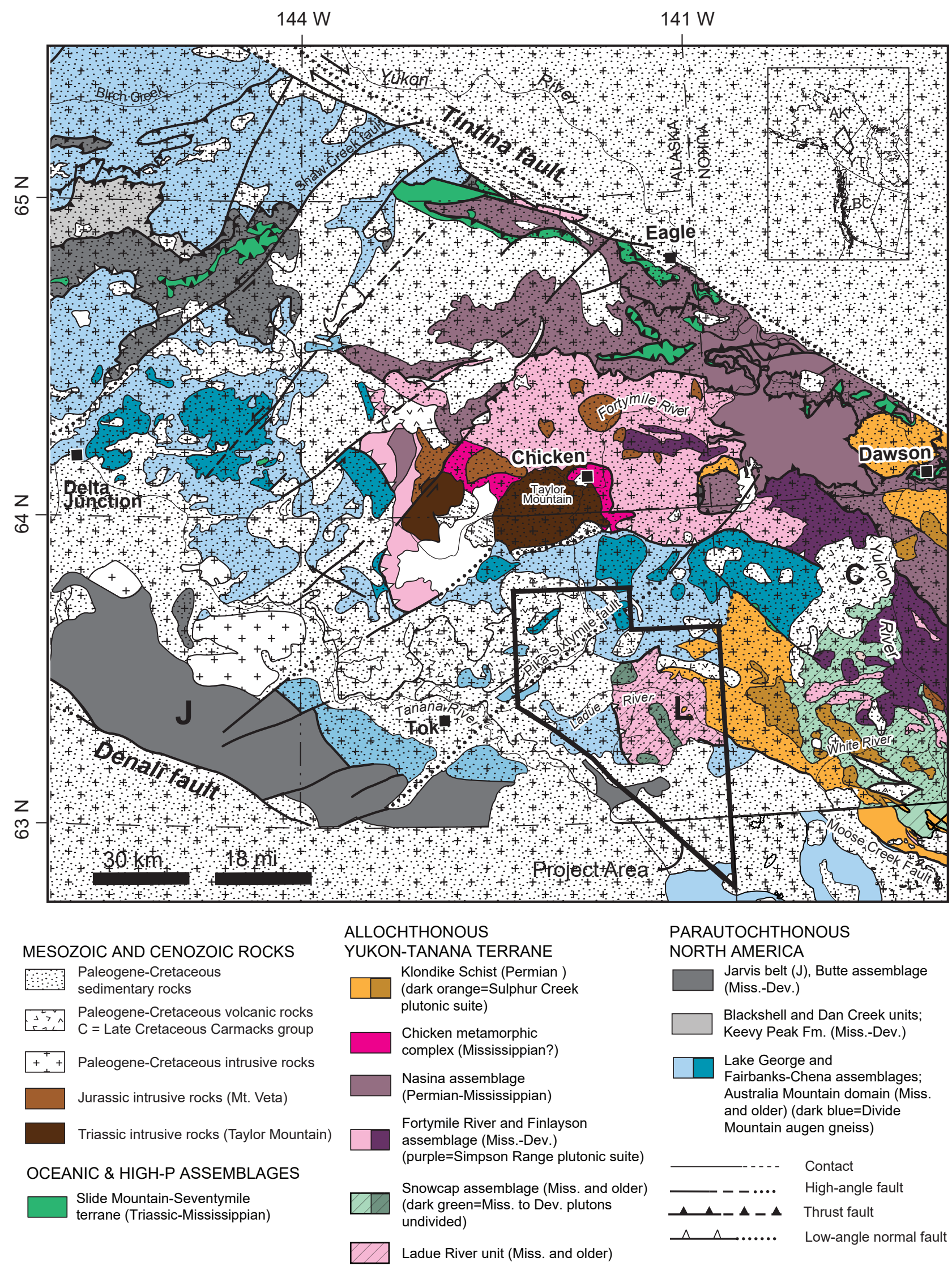

Figure 2. Generalized regional geologic map, adapted from Dusel-Bacon and others (2017; with modifications by James V. Jones III, USGS). "C" indicates Late Cretaceous Carmacks Group volcanic rocks; "L" indicates the Ladue River unit; "J" indicates Jarvis belt. 
Table 1. Selected U-Pb zircon age analyses used in the construction of this map. References: (1) LA-ICP-MS ages reported in Wildland and others (2021); (2) SHRIMP ages reported in Dusel-Bacon and others (2015); (3) TIMS age reported in Dusel-Bacon and others (2006); (4) Jones and O'Sullivan (2020).

\begin{tabular}{|c|c|c|c|c|c|c|c|c|}
\hline Sample & $\begin{array}{l}\text { Map } \\
\text { unit }\end{array}$ & Lithology & Latitude & Longitude & $\begin{array}{l}\text { Weighted } \\
\text { mean age }\end{array}$ & $\begin{array}{l}\text { Uncertainty } \\
\text { (2 sigma) }\end{array}$ & MSWD & Ref. \\
\hline $19 K S 100$ & Pefp & granite porphyry & 63.5197 & -141.3235 & 57.1 & 1.2 & 1.5 & 1 \\
\hline $19 \mathrm{ET} 277$ & Pefp & rhyolite & 63.3828 & -141.8030 & 58.6 & 1.4 & 1.0 & 1 \\
\hline 19AW256 & $\mathrm{Per}$ & rhyolite & 63.4673 & -142.4666 & 58.9 & 1.4 & 1.0 & 1 \\
\hline 08ADb13 & IKgqm & quartz monzonite & 63.6547 & -142.2903 & 66.5 & 1.1 & - & 2 \\
\hline 08ADb14 & IKsy & syenite & 63.6819 & -141.2581 & 67.0 & 1.5 & - & 2 \\
\hline 19RN287 & IKpg & porphyritic granite & 63.3791 & -141.8164 & 68.8 & 1.5 & 0.9 & 1 \\
\hline 19WCW037 & IKgd & granodiorite & 63.5726 & -141.4382 & 69.3 & 1.4 & 1.3 & 1 \\
\hline 19RN359 & $\mathrm{IKfd}$ & felsic dike & 63.6871 & -142.2587 & 70.5 & 1.6 & 1.9 & 1 \\
\hline 19TJN243 & $\mathrm{IKgd}$ & granodiorite & 63.3848 & -141.8155 & 71.4 & 1.4 & 2.1 & 1 \\
\hline 19RN282 & $\mathrm{IKgd}$ & granodiorite & 63.3836 & -141.8037 & 72.1 & 1.6 & 1.1 & 1 \\
\hline 19ADW053 & Kmd & monzonite & 63.2340 & -141.2208 & 100.3 & 2.2 & 3.3 & 1 \\
\hline 19ADW016 & Kmi & felsic dike & 63.0578 & -141.0771 & 102.8 & 2.2 & 3.3 & 1 \\
\hline 19ET054 & Kgd & granodiorite & 63.1975 & -141.0479 & 104.2 & 2.3 & 1.7 & 1 \\
\hline 19ET288 & $\mathrm{Kg}$ & granite & 63.3617 & -141.8630 & 106.7 & 2.3 & 1.6 & 1 \\
\hline 19AW200 & Kgp & granite porphyry & 63.3948 & -142.3554 & 107.2 & 2.4 & 2.5 & 1 \\
\hline 19JEA029 & Kgd & granodiorite & 63.2619 & -141.1235 & 107.7 & 2.3 & 1.3 & 1 \\
\hline $19 \mathrm{ET} 146$ & $\mathrm{Kg}$ & granite & 63.4919 & -141.6891 & 107.9 & 2.4 & 0.9 & 1 \\
\hline 19TJN299 & Kwff & felsic tuff & 63.7295 & -142.3061 & 107.9 & 2.2 & 1.3 & 1 \\
\hline 19SPR027 & Kgb & diorite & 63.3172 & -142.1020 & 108.1 & 2.3 & 2.7 & 1 \\
\hline 19WCW039 & $\mathrm{Kg}$ & granite & 63.5658 & -141.4154 & 109.1 & 2.2 & 12.0 & 1 \\
\hline 19RN222 & Kgp & granite porphyry & 63.3957 & -142.1532 & 109.2 & 2.4 & 1.5 & 1 \\
\hline 19TJN181 & $\mathrm{Kg}$ & granite & 63.3958 & -142.1536 & 109.7 & 2.2 & 2.9 & 1 \\
\hline 19ET102 & Kmi & porphyry dike & 63.5203 & -141.3252 & 110.7 & 2.5 & 1.2 & 1 \\
\hline 19TJN231 & Kgp & granite porphyry & 63.5260 & -142.3200 & 111.8 & 2.2 & 2.0 & 1 \\
\hline 19RN423 & $\mathrm{Kg}$ & granite & 63.7192 & -141.8181 & 112.8 & 2.6 & 2.6 & 1 \\
\hline 19SPR102 & Kgp & granite porphyry & 63.6166 & -142.2189 & 115.0 & 2.5 & 4.0 & 1 \\
\hline 19ET098 & Pks & schist & 63.5173 & -141.1760 & 256.7 & 5.8 & 1.0 & 1 \\
\hline $19 \mathrm{ET} 126$ & Pks & schist & 63.3351 & -141.0576 & 261.4 & 5.8 & 0.9 & 1 \\
\hline 16AJJ219D & Pks & schist & 63.4611 & -141.2739 & 267.0 & 3.7 & 2.4 & 4 \\
\hline 16AJJ275B & MDpo & augen orthogneiss & 63.3446 & -141.3502 & 352.1 & 7.1 & 1.8 & 4 \\
\hline 14AJJ019 & $\mathrm{MDg}$ & metagranitoid & 63.3040 & -141.4625 & 354.5 & 2.7 & 1.5 & 4 \\
\hline 16AJJ250A & MDpo & orthogneiss & 63.4557 & -141.3745 & 355.5 & 11.5 & 1.16 & 4 \\
\hline 14AJJ016 & MDpo & orthogneiss & 63.3104 & -141.4639 & 356.7 & 4.1 & - & 4 \\
\hline 19WCW048 & MDpo & orthogneiss & 63.2706 & -141.2756 & 359.7 & 7.2 & 2.3 & 1 \\
\hline 19ADW351C & MDag & granite orthogneiss & 63.6588 & -141.7359 & 360.7 & 8.7 & 0.8 & 1 \\
\hline 19ET045 & $\mathrm{MDg}$ & metagranitoid & 63.2652 & -141.1283 & 360.7 & 7.8 & 4.0 & 1 \\
\hline 19ET158 & $\mathrm{MDa}$ & amphibolite & 63.3207 & -141.6333 & 361.8 & 7.4 & 1.6 & 1 \\
\hline 00ADb59 & MDg & schist & 63.478 & -141.604 & 362.9 & 1.4 & - & 3 \\
\hline 19AW285 & $\mathrm{MDg}$ & metagranitoid & 63.3916 & -141.9208 & 363.0 & 7.9 & 1.7 & 1 \\
\hline 14AJJ025 & MDg & orthogneiss & 63.2915 & -141.4343 & 363.4 & 5.2 & 2.1 & 4 \\
\hline 19WCW067 & $\mathrm{MDg}$ & metagranitoid & 63.2584 & -141.6044 & 364.9 & 7.3 & 1.7 & 1 \\
\hline 14AJJ013 & $\mathrm{MDg}$ & orthogneiss & 63.2199 & -141.3789 & 365.0 & 3.3 & 1.2 & 4 \\
\hline 16AJJ211 & $\mathrm{MDg}$ & metagranitoid & 63.3438 & -141.3678 & 365.1 & 5.1 & 1.4 & 4 \\
\hline 19ET034 & MDmr & metarhyolite & 63.0598 & -141.4573 & 366.8 & 8.1 & 2.2 & 1 \\
\hline 19SPR174 & MDag & granite & 63.6587 & -141.7359 & 367.6 & 8.4 & 5.8 & 1 \\
\hline 17AJJ108 & $\mathrm{MDg}$ & metagranitoid & 63.2609 & -141.3951 & 368.3 & 4.9 & 1.8 & 4 \\
\hline 19RN278 & $\mathrm{MDg}$ & metagranitoid & 63.4027 & -141.7008 & 370.1 & 8.4 & 0.9 & 1 \\
\hline 19ADW202 & MDlo & leucogranite & 63.2561 & -141.8652 & 370.6 & 8.3 & 2.7 & 1 \\
\hline 19SPR004 & $\mathrm{MDg}$ & metagranitoid & 63.4218 & -142.2953 & 375.7 & 9.0 & 1.1 & 1 \\
\hline
\end{tabular}


Table 2. Sample locations and youngest statistical population (YSP) maximum depositional ages (MDAs) for the detrital zircon samples used in construction of this map. MDAs for all samples are reported in Twelker and O'Sullivan (2021b); the original data for 19 KS149 is from Jones and O'Sullivan (2020).

\begin{tabular}{cccccccc} 
Sample & $\begin{array}{c}\text { Latitude } \\
\text { (WGS84) }\end{array}$ & $\begin{array}{c}\text { Longitude } \\
\text { (WGS84) }\end{array}$ & Map unit & $\begin{array}{c}\text { Lithology } \\
\text { 19ET330 }\end{array}$ & $\begin{array}{c}\text { YSP (Ma) } \\
\mathbf{\pm} \mathbf{2} \sigma\end{array}$ & MSWD & $\begin{array}{c}\text { n (YSP) / } \\
\text { n sample }\end{array}$ \\
\hline 19KS430 & 63.6982 & -141.7433 & IKav & $\begin{array}{c}\text { Volcaniclastic } \\
\text { conglomerate }\end{array}$ & $65.8 \pm 1.9$ & 1.05 & $12 / 110$ \\
\hline 19AW206 & 63.3867 & -142.3942 & GKs & Conglomerate & $103.2 \pm 2.2$ & 0.99 & $20 / 110$ \\
\hline $19 K S 149$ & 63.3912 & -141.1216 & GrKs & Conglomerate & $54.0 \pm 1.1$ & 1.00 & $70 / 110$ \\
\hline
\end{tabular}

others, 2006, and references therein). The YTT was then accreted to North America during the Mesozoic (Dusel-Bacon and others, 2002; Dusel-Bacon and others, 2015). Extensive mid-Cretaceous magmatism affected both the YTT and pNA, indicating YTT accretion occurred prior to that time. Low-angle ductile extensional shear zones were also developed between the YTT and pNA assemblages in the mid-Cretaceous (Hansen and others, 1991; Pavlis and others, 1993; Dusel-Bacon and others, 2002). Additional periods of magmatism during the Late Cretaceous and Early Paleogene are recorded by both volcanic and intrusive units in the map area (Foster, 1970; Bacon and others, 1990; Solie and others, 2014). Finally, the area was extensively modified by Cenozoic high-angle faults, resulting in the current complex exposure of the YTT-parautochthon boundary (Sánchez and others, 2014; Solie and others, 2019; Wypych and others, 2021).

\section{Parautochthonous North American Assemblages}

The rocks of pNA include metamorphosed siliciclastic sedimentary rocks thought to have been deposited along the continental margin of Laurentia, including the Lake George assemblage, Divide Mountain augen gneiss, and Jarvis belt (discussed below). Detrital zircon data from pNA units indicate derivation from Archean to Proterozoic source rocks (Dusel-Bacon and others,
2017). The pNA units in Alaska are thought to be the metamorphosed equivalent of Paleozoic to Neoproterozoic continental margin rocks of the Selwyn Basin in Yukon (Mair and others, 2006). Sedimentary protoliths are interlayered with, or intruded by, Late Devonian to Early Mississippian felsic and mafic metaigneous rocks.

Parautochthonous North American rocks in eastern Alaska are characterized by subhorizontal-dominant foliations, which are at least the second generation of foliation in most locations. An older foliation that is folded into tight isoclinal folds is observed at many localities. Mid-Cretaceous ${ }^{40} \mathrm{Ar} /{ }^{39} \mathrm{Ar}$ cooling ages in pNA are characteristic, in contrast to Jurassic to Permian ${ }^{40} \mathrm{Ar} /{ }^{39} \mathrm{Ar}$ cooling ages in the YTT (Dusel-Bacon and others, 2002; Naibert and others, 2020; Jones and Benowitz, 2020). The pNA units are intruded by Late Devonian-Early Mississippian intrusions, metamorphosed to orthogneiss, and by Cretaceous to Paleogene intrusions as old as approximately 114 Ma (for example, Dusel-Bacon and others, 2015; Solie and others, 2014; Wypych and others, 2020; Jones and O'Sullivan, 2020). Permian to Jurassic intrusions that are common in the YTT are absent from the pNA units.

\section{Lake George Assemblage}

The Lake George assemblage extends north of the Tanana River in eastern Alaska from the Yukon border to the Salcha River area (Dusel-Bacon and 
others, 2006). The assemblage is a mix of amphibolite-facies quartzite, paragneiss, and quartzose schists, along with interlayered amphibolites and abundant Late Devonian-Early Mississippian orthogneiss bodies. Orthogneiss bodies within the Lake George assemblage have dioritic to granitic composition and are fine- to medium-grained. Intrusive contacts are often poorly exposed but are generally concordant with foliation. In the northeastern Tanacross quadrangle, the orthogneiss layers are interpreted to have been intruded as dikes, sills, and small plutons with thicknesses from $30 \mathrm{~cm}$ to $300 \mathrm{~m}$ (Wypych and others, 2021), which were metamorphosed and deformed with their host rocks. Zircon $\mathrm{U}-\mathrm{Pb}$ ages from orthogneiss samples in the eastern Tanacross Quadrangle are Late Devonian (ca. 371-376 Ma; Jones and O'Sullivan, 2020; Todd and others, 2019).

\section{Divide Mountain Augen Gneiss}

The Divide Mountain augen gneiss is a suite of megacrystic granitoid plutons metamorphosed to amphibolite-facies augen orthogneiss (DuselBacon and Aleinikoff, 1996; Dusel-Bacon and Williams, 2009) like the bodies of augen gneiss initially described by Dusel-Bacon and Aleinikoff (1985). This unit was previously included in the Lake George assemblage (Dusel-Bacon and others, 2006) and was first divided into a subunit in the northeastern Tanacross quadrangle by Wypych and others (2021). We separate the Divide Mountain augen gneiss in our map area and throughout the Yukon-Tanana Upland from the mostly metasedimentary and metavolcanic Lake George assemblage as a Late Devonian-Early Mississippian intrusive suite because of observed crosscutting contacts with the Lake George assemblage, as well as to match the practice of dividing intrusive suites and host rocks into different units as practiced in Yukon (for examples see Yukon Geological Survey, 2019). Pluton contacts are observed to be both crosscutting and interlayered within the Lake George assemblage, and the augen gneiss is interpreted to have been metamorphosed and deformed with the Lake George assemblage. Zircon U-Pb ages in the region range from ca. 371 to $347 \mathrm{Ma}$ (DuselBacon and others, 2006; Todd and others, 2019; Jones and O'Sullivan, 2020; Wildland and others, 2021). In the Tok River area, augen gneiss intrudes the Macomb belt (Sicard and others, 2017), which is a possible correlative of the Lake George assemblage in the Alaska Range (Dusel-Bacon and others, 2006). Similar augen orthogneiss has been documented throughout the eastern Yukon Tanana Upland, mostly to the east of the northeast-striking Shaw Creek fault (fig. 2).

\section{Jarvis Belt}

The Jarvis belt is a mixed unit of felsic metavolcanic, metavolcaniclastic, and siliciclastic rocks, which are mostly metamorphosed to greenschist-facies, though samples from the Ladue RiverMount Fairplay map area include relict amphibolite-facies mineralogy. The Jarvis belt is extensively exposed in the Tok River area (Sicard and others, 2017), along the Alaska Highway (Solie and others, 2019), and the Delta mineral belt (Dashevsky and others, 2003), where it is further subdivided by lithology. Metavolcanic rocks from the Jarvis belt have Mississippian-Devonian U-Pb zircon ages, which suggests that the unit may represent a volcanic arc of that age that is stratigraphically and (or) structurally above the Lake George assemblage and the Divide Mountain augen gneiss intrusions of similar age (Nokleberg and Aleinikoff, 1985; Dashevsky and others, 2003). However, unlike the Lake George assemblage, the Jarvis belt is intruded by Triassic (?) gabbro sills, which are parallel or subparallel to foliation and lithologic contacts.

A possible correlative of the Jarvis belt is the White River assemblage in western Yukon. The White River assemblage includes the basal Scottie Creek formation and the overlying White River Complex, and intrusions of the Devonian Mount Baker plutonic suite (Ryan and others, 2013, 2014). The Scottie Creek formation is dominantly quartzite and muscovite schist well as quartzofeldspathic schist (Ryan and others, 2014). The White River Complex includes Late Devonian metavolcanic rocks and minor carbona- 
ceous schist. Metavolcanic protolith ages from the White River assemblage, as well as similar lithologies, suggest a correlation to the Jarvis belt rocks in the Tok River area. The ca. 375 Ma Mount Baker plutonic suite may be correlative with the fine-to medium-grained orthogneiss within the Lake George assemblage (Ryan and others, 2014). The White River assemblage is also intruded by Triassic gabbro and diabase of the Snag Creek suite (Ryan and others, 2014), which are similar to the gabbro sills in the Jarvis belt of the Tok River area (Sicard and others, 2017), the Alaska Highway corridor (Solie and others, 2019), and the Delta mineral belt (Dashevsky and others, 2003).

\section{Yukon Tanana Terrane Assemblages}

The complexly deformed Yukon Tanana Terrane is generally interpreted as a series of Mississippian to Permian volcanic arcs developed on a basement of pre-Devonian metasedimentary continental margin rocks rifted from North America during the Late Devonian to Early Mississippian (Colpron and others, 2006). Regional units of the YTT include the Snowcap, Finlayson, Fortymile River, Nasina, and Klondike assemblages. The YTT within the area is known as the Ladue River unit (Dusel-Bacon and others, 2006) and it has an incompletely resolved relationship to these regional units (see discussion below and in chapters B and C). The metamorphic assemblages of the YTT are polydeformed and likely experienced multiple periods of metamorphism. Jurassic-Triassic plutons intrude the YTT, including the Taylor Mountain batholith and surrounding plutons (Werdon and others, 2001), the Mount Veta batholith (Dusel-Bacon and others, 2013), and the Aishihik plutonic suite in Yukon (Ryan and others, 2013), and do not intrude the parautochthonous units, indicating collision and thrust faulting of the YTT over pNA did not occur until the Early Jurassic. Fortymile River and Finlayson assemblage ${ }^{40} \mathrm{Ar} /{ }^{39} \mathrm{Ar}$ cooling ages are mostly Early Jurassic (Dusel-Bacon and others, 2002; Naibert and others, 2020; Jones and Benowitz, 2020; Yukon Geological Survey, 2019), which record the timing of erosional exhumation during collision and thrust faulting of YTT over pNA. Cooling ages in the Klondike assemblage and parts of the Ladue River unit are Permian to Triassic, indicating that these units may have been structurally higher and had already exhumed through the argon closure temperatures of muscovite and biotite prior to Early Jurassic collision (Jones and Benowitz, 2020).

\section{Snowcap and Finlayson Assemblages}

The metasedimentary basement rocks of YTT are mapped in Yukon as the Snowcap assemblage and presented here as a possible regional correlation for rocks of the Ladue River unit. The interpretation of the Snowcap assemblage as a rifted part of the North American continental margin is supported by lithologies broadly equivalent to the Lake George assemblage in pNA and pre-Devonian detrital zircon populations similar to continental margin rocks (Nelson and others, 2006, Piercey and Colpron, 2009). The geochemistry of Snowcap amphibolites, enriched mid-ocean ridge basalt (E-MORB) and ocean-island basalt (OIB), is most likely related to one of several Neoproterozoic to early Paleozoic continental rifting events that affect the Laurentian margin (Piercey and Colpron, 2009). The Snowcap assemblage is commonly intruded by the Early Mississippian Simpson Range plutonic suite and, locally, by the Late Devonian Grass Lakes plutonic suite (Colpron and others, 2006). The unit is also intruded by orthogneiss of the Permian Sulphur Creek plutonic suite, which is interpreted as the roots of the Klondike assemblage volcanic arc (discussed below). A 365 Ma detrital zircon population in the Stevenson Ridge area in western Yukon adjacent to our map area suggests continued sediment deposition following or coeval with Devonian pluton emplacement (Ryan and others, 2014) and Lower Mississippian felsic metavolcanic rocks in the upper part of the correlative Dorsey Complex in southern Yukon suggest at least local transition into the overlying Finlayson assemblage (Colpron and others, 2006).

Widespread Upper Devonian to Lower Mississippian bimodal metavolcanic rocks in Yukon are assigned to the Finlayson assemblage and represent 
both arc and back-arc magmatism (Colpron and others, 2006) following rifting of YTT from North America. The Finlayson assemblage also includes related volcaniclastic metasedimentary rocks, recycled siliciclastic rocks, and locally thick marble layers. In the Stevenson Ridge area, Yukon, the Finlayson assemblage includes massive amphibolite layers interpreted as mafic flows or sills, which are locally in structural contact with Snowcap assemblage rocks (Ryan and others, 2014).

Two Late Devonian to Mississippian plutonic suites intrude the Snowcap and Finlayson assemblages in Yukon: The Grass Lakes and the Simpson Range plutonic suites. Both plutonic suites are metamorphosed and deformed to orthogneiss of varying textures. The Grass Lakes plutonic suite was intruded into the Snowcap assemblage and the lower parts of the Finlayson assemblage in the eastern Finlayson Lake district during the Late Devonian and earliest Mississippian (Colpron and others, 2006; Piercey and others, 2006). The Grass Lakes plutonic suite is interpreted by Piercey and others (2006) to represent within-plate magmatism in a back-arc setting. Grain size varies considerably within the Grass Lakes suite, including large feldspar porphyroclasts in some localities. The Early Mississippian Simpson Range plutonic suite intrudes the Snowcap assemblage and the Finlayson assemblage in Yukon. The Simpson Range plutons are the primary record of arc magmatism in the Finlayson assemblage in the Finlayson Lakes district and in the Stewart River area (Piercey and others, 2006), and have tonalitic-dioritic-granodioritic compositions.

\section{Fortymile River Assemblage}

The Fortymile River assemblage in eastern Alaska is correlative with the Finlayson assemblage and is exposed in the northeast Tanacross Quadrangle (Wypych and others, 2021) and adjacent parts of the Eagle Quadrangle (Werdon and others, 2001, Szumigala and others, 2002); it is presented here for purposes of comparison to the Ladue River unit of this map. The Fortymile River assemblage includes interlayered orthogneiss, paragneiss, quartz schist, and locally thick marble layers. Interlayered amphibolites up to 10's of meters thick are also common. The abundance of granodiorite-tonalite composition orthogneiss bodies within the Fortymile River assemblage matches the description of voluminous orthogneiss of the Simpson Range plutonic suite within the Finlayson assemblage in the Stewart River area across the Yukon-Alaska border (Colpron and others, 2006). The dominance of orthogneiss in these areas was interpreted by Colpron and others (2006) as a more deeply exhumed part of the Finlayson assemblage volcanic arc system.

\section{Klondike Assemblage}

The Klondike assemblage in the Stewart River, Stevenson Ridge, and Dawson areas in Yukon consists of Middle to Late Permian metavolcanic rocks and interbedded metasedimentary rocks (Colpron and others, 2006). Greenschist-facies felsic metavolcanic rocks define the Klondike schist in the Stewart River and Stevenson Ridge areas, which also includes minor mafic metavolcanic rocks (Gordey and Ryan, 2005; Ryan and others, 2014). The Klondike schist metavolcanic rocks are generally interpreted as a volcanic arc. The Sulphur Creek plutonic suite represents the magmatic roots of the Klondike schist and shares the same composition and Permian ages (ca. 262 to $257 \mathrm{Ma}$ ) (Beranek and Mortenson, 2011; Ryan and others, 2014). Sulphur Creek plutons intrude the Klondike schist as well as the underlying Snowcap and Finlayson assemblages over a large area in western Yukon (Milidragovic and others, 2016).

\section{Ladue River Unit}

The Ladue River unit, initially defined by Dusel-Bacon and others (2006), is a subregional unit with incompletely understood relationships to the previously described regional units of the YTT. The unit was first mapped by Foster (1970), who recognized a body of mostly greenschist-facies schist and suggested a correlation to the Klondike schist of Cockfield (1921) in the adjacent Yukon. Dusel-Bacon and others (2006) described a mix of sedimentary, volcanic, and granitic protoliths 
and characterized the unit as upper greenschist to lower amphibolite-facies rocks variably retrograded to greenschist facies. A schistose metaigneous rock (00ADb59; table 1) yielded a Late Devonian $\mathrm{U}-\mathrm{Pb}$ zircon age, precluding a simple correlation of this unit to the Permian Klondike assemblage (Dusel-Bacon and others, 2006). Further U-Pb and ${ }^{40} \mathrm{Ar} /{ }^{39} \mathrm{Ar}$ geochronology by the USGS led to the recognition that the original Ladue River unit includes both Permian rocks and Mississippian or older rocks of less certain regional correlation (Jones and others, 2017). In our map and report, the Permian rocks have been removed from the Ladue River unit and assigned to the Klondike assemblage units (Pks, Pkmb, Pkgs). The Mississippian and older units (MDg, MDpo, MDa, MPms) may be correlated to the Fortymile River assemblage, the Snowcap assemblage, or both. Our observations, presented with the unit descriptions and in chapters $B$ and $C$, suggest a partial similarity to the Fortymile River assemblage. However, we also observe that the Ladue River unit lacks Triassic and Jurassic intrusions found in the Fortymile River assemblage and may have older ${ }^{40} \mathrm{Ar} /{ }^{39} \mathrm{Ar}$ cooling ages than the Fortymile River or Snowcap assemblages (Jones and Benowitz, 2020).

\section{Seventymile Terrane}

The Seventymile terrane in eastern Alaska is a widespread series of fault-bound slices of variably serpentinized harzburgite and dunite, weakly metamorphosed mafic volcanic rocks and gabbros, and Mississippian to Upper Triassic chert and other marine sedimentary rocks (Dusel-Bacon and others, 2006). The Seventymile terrane is considered to be equivalent to the Slide Mountain assemblage in Yukon and British Columbia (Colpron and others, 2006). The Slide Mountain assemblage in Yukon is well exposed in the Finlayson Lake district, where it includes weakly metamorphosed Permian basalts of the Campbell Range formation (Colpron and others, 2006). The Seventymile terrane is generally interpreted as a dismembered ophiolite sequence (Keith and others, 1981; Foster and others, 1994). Large fault slices of the Seventymile terrane are mapped in the Salcha River, Mount Sorenson, and American Creek areas in Alaska, and Clinton Creek in Yukon, and smaller serpentinized bodies occur throughout eastern Alaska and western Yukon (Dusel-Bacon and others, 2006). The smaller occurrences often have slip-fiber serpentine or other alteration that indicate slip-along contacts. The Seventymile terrane and Slide Mountain assemblages are interpreted as slices of oceanic crust obducted onto the YTT and North American margin during collision and their presence as thrust slices may indicate the location of major terrane boundaries (Colpron and others, 2006; Dusel-Bacon and others, 2006; Nelson and others, 2006).

\section{Mesozoic to Cenozoic Magmatism}

Mesozoic to Cenozoic magmatism in the region surrounding the study area spans from Triassic through to the Quaternary. The earliest Mesozoic magmatic rocks in the region include the Taylor Mountain Batholith and nearby intrusions (Werdon and others, 2001; Dusel-Bacon and others, 2015; Wypych and others, 2021), and the Early Jurassic plutonic rocks including the Mount Veta pluton (Dusel-Bacon and others, 2013); these units represent two pulses of arc magmatism above an east-dipping subduction zone (Dusel-Bacon and others, 2002; Dusel-Bacon and others, 2015). The Triassic and Jurassic intrusions are restricted to the allochthonous YTT in the Eagle and northeast Tanacross quadrangles; we did not observe magmatic rocks of these ages in the YTT units present in our study area.

The region experienced a magmatic lull during the period 179-115 Ma, followed by renewed magmatism ca. 115-98 Ma above a northeast-dipping subduction zone (Allan and others, 2013). Rocks of this age intrude primarily pNA and to a lesser extent YTT, indicating that the two terranes were proximal to each other by this time, if not finally sutured following mid-Cretaceous extensional faulting. They include batholith-scale intrusions, including the Dawson Range batholith, Yukon (Hart and others, 2004), granite porphyry dikes, and 
thick felsic volcanic deposits, interpreted as remnant calderas, at several locations in the Tanacross Quadrangle (Bacon and others, 1990). The wide range of depths of exposure reflects the differential uplift that has affected the area since the mid-Cretaceous.

Magmatic quiescence in the region corresponds to deposition of a Late Cretaceous continental sedimentary succession, the Indian River Formation in Yukon (Lowey and Hills, 1988). Arc magmatism resumed in the Late Cretaceous, expressed as relatively small intrusions including the Casino plutonic suite (ca. 79-72 Ma) and intrusions at the Taurus prospect area in the northeastern Tanacross Quadrangle (ca. 72-67 Ma; Allan and others, 2013; Kreiner and others, 2019; Wypych and others, 2020). This phase of magmatism hosts porphyry copper-molybdenum-gold mineralization at the Casino and Taurus deposits, among others (Allan and others, 2013). Younger, latest-Cretaceous (ca. 70-66 Ma) magmatism includes alkaline as well as calc-alkaline volcanic rocks of the Carmacks Group in Yukon (Allan and others, 2013) and the Middle Fork caldera in the southwestern Eagle Quadrangle (Bacon and others, 2014). The alkaline rocks of the Mount Fairplay complex were emplaced at this time, as were the intermediate, calc-alkaline volcanic rocks of the Tanacross D-1 Quadrangle (Wypych and others, 2021).

The last significant phase of magmatism in the eastern Yukon-Tanana Upland occurred during the Paleocene to Eocene (ca. 60-55 Ma). This phase includes mainly felsic (and locally mafic) dikes, plugs, and volcaniclastic rocks known as the Rhyolite Creek complex, as well as the Ruby Range plutonic suite in western Yukon (Allan and others, 2013). Scattered, volumetrically minor bimodal (mafic and felsic) volcanic and intrusive rocks are a broadly distributed throughout the Yukon-Tanana Upland (for example, Newberry and others, 1996; Werdon and others, 2001, Dilworth, 2003, Twelker and O'Sullivan, 2021a). The geochemistry of these rocks (see chapter $\mathrm{E}$ ) suggests they originated in an extensional environment (Flanigan and others, 2000), possibly related to motion along the Tintina fault and related structures (Allan and others, 2013).

\section{Mesozoic and Cenozoic Faults}

The YTT was internally imbricated and thrust over pNA and the Selwyn Basin by the Early to Middle Jurassic. The Seventymile/Slide Mountain terrane defines the suture zone between YTT and North America along much of the terrane boundary and is thought to represent the intervening ocean basin that closed prior to YTT accretion (Colpron and others, 2006). Thrust faults within the YTT and the Slide Mountain terrane are well mapped in the Finlayson Lake area in Yukon (Murphy and others, 2006). The extents of other thrust faults mapped in the YTT, such as the Yukon River Shear Zone (Parsons and others, 2018), are unclear because the fault traces are covered by Cretaceous volcanic or sedimentary rocks or have been reactivated during mid-Cretaceous extension. Thrust vergence on the Cleaver Lake and Money Creek thrusts in the Finlayson Lake district is northeast-directed and is interpreted as Early Permian by Murphy and others (2006). Top-to-the-northeast shear is also recorded in the Fortymile River assemblage in eastern Alaska, which is interpreted as pre-Late Triassic $(-212 \mathrm{Ma})$ shear (Hansen and Dusel-Bacon, 1998). Thrust vergence on the Yukon River shear zone is northwest-directed (Parsons and others, 2018) and matches a second shear direction in the Fortymile River assemblage, which is top-to-the-northwest and is interpreted as Late Triassic-Early Jurassic (Hansen and Dusel-Bacon, 1998).

A low-angle shear zone is poorly exposed between the Fortymile River assemblage of YTT and the parautochthonous Lake George assemblage and Divide Mountain augen gneisses in the northeast Tanacross map area (Hansen and Dusel-Bacon, 1998; Wypych and others, 2021). Jurassic ${ }^{40} \mathrm{Ar} /{ }^{39} \mathrm{Ar}$ cooling ages in the hanging wall of the shear zone and mid-Cretaceous ${ }^{40} \mathrm{Ar} /{ }^{39} \mathrm{Ar}$ cooling ages in the footwall suggest the shear zone is an extensional detachment (Dusel-Bacon and others, 2002; Naibert and others, 2020). Hansen and DuselBacon (1998) report top-to-the-southeast shear in 
the detachment zone and throughout the footwall rocks. Similar mid-Cretaceous extension is proposed for other low-angle extensional structures in eastern Alaska, such as the Salcha River gneiss dome (Pavlis and others, 1993; Hansen and Dusel-Bacon, 1998).

The right-lateral Denali and Tintina faults are major crustal features that bound the Yukon Tanana Upland in eastern Alaska. A prominent set of northeast-striking faults cuts the upland between these two faults. These faults are interpreted to have left-lateral-oblique motion (Day and others, 2014) and are intruded by mid-Cretaceous intrusions in multiple places, indicating northeast-striking faults are at least that old. Northeast-striking faults offset
Holocene deposits in some locations, indicating that some of the faults are long-lived features in the late Mesozoic through the Cenozoic (Day and others, 2014) or that multiple episodes of faulting occurred along similarly oriented faults. Additional high-angle fault orientations, including northwest-southeast, are also mapped in the region but are less-well understood (for example, Gordey and Ryan, 2005; Solie and others, 2019; Wypych and others, 2021). Interpreting the map patterns of Triassic to Jurassic contractional and mid-Cretaceous extensional structures separating the YTT from pNA are complicated by subsequent Cenozoic motion on these high-angle faults.

\section{DESCRIPTION OF MAP UNITS Sedimentary Rocks}

GrKs SEDIMENTARY ROCKS (CENOZOIC-CRETACEOUS)—Mixed unit of poorly-sorted, volcaniclastic to siliciclastic conglomerate and sandstone. Conglomerate grain size varies between locations, with cobbles commonly up to $10 \mathrm{~cm}$ and rare boulders up to $50 \mathrm{~cm}$ in diameter. Clasts vary from subangular to subrounded, and volcanic clasts typically dominate the coarse fraction, but metamorphic lithologies and detrital quartz and feldspar are also present, particularly among the smaller fraction. Volcanic clasts include dacite, rhyolite, and rhyolite tuff. The matrix ranges from poorly sorted brown tuffaceous silt to fine-grained plagioclase- and quartz-rich sand and silt. Sandstones are typically fine- to medium-grained, laminated, and poorly to moderately indurated. The unit has low to moderate magnetic susceptibility with a range of $0.01 \times 10^{-3}$ to $10.89 \times 10^{-3}$ Système International units (SI), with an average of $2.11 \times 10^{-3}$ SI and a median of $0.15 \times 10^{-3} \mathrm{SI}$.

Depositional ages of rocks included in this unit range from mid-Cretaceous through Miocene or younger, and multiple ages may be present in a single exposure (for example, see Foster and Igarashi, 1990). Consequently, the unit has depositional relationships with the Late Cretaceous and Paleogene volcanic rocks that would be problematic if it had a single discrete age. In the northwest quadrant of the map, unit GrKs lies stratigraphically above the West Fork Tuff (Kwff; 107.9 \pm 2.2 Ma; Wildland and others, 2021) and below the Late Cretaceous (?) alkaline volcanic rock unit (IKav); detrital zircons indicate mid-Cretaceous $(101.2 \pm 2.2 \mathrm{Ma})$ maximum depositional age (MDA) that is consistent with this stratigraphic relationship (19KS430; table 2; Twelker and O'Sullivan, 2021b). South of Mount Fairplay along the Taylor Highway, Foster and Igarashi (1990; site 2) report a fossil pollen assemblage that they interpret as representing a Miocene or younger depositional age, while $10 \mathrm{~km}$ to the south an isolated conglomerate exposure yielded a mid-Cretaceous detrital zircon MDA (19AW206; Twelker and O'Sullivan, 2021b). In the eastern map area, an isolated conglomerate exposure yielded a $-54 \mathrm{Ma}$ detrital zircon MDA (19KS149; Jones and O'Sullivan, 2020; Twelker and O'Sullivan, 2021b).

Similar sedimentary units are described by Wypych and others (2021) in the adjoining Northeast Tanacross map area, but the conglomerates in that area contain fewer volcanic clasts and more metamorphic clasts. This unit may correlate with the Indian River Formation in Yukon, which also consists of mixed conglomerates and sandstones that lie stratigraphically below the Late Cretaceous Carmacks volcanic 
group. Lowey and Hills (1988) assigned an Albian (ca. 113-100 Ma) age to the Tantalus Formation (Indian River Formation of Yukon Geological Survey, 2019) based on the presence of Albian palynomorphs. Conglomerates with Neogene depositional age may correlate with those in the Chicken area, as well as those north of Mount Fairplay (Foster and Igarashi, 1990).

\section{Volcanic rocks}

Per RHYOLITE (PALEOGENE) - Porphyritic rhyolite lava flows and lesser felsic tuff and volcaniclastic rocks. Rhyolite has an aphanitic groundmass, and phenocrysts include 2-mm-diameter quartz (10 percent), 1-mm-long feldspar (5 percent), and 3 percent angular lithic clasts of volcanic material in a devitrified matrix. Some flow banding is present. Liesegang-banded ash fall tuff is white to tan, with up to 5 percent quartz, 2 percent feldspar, and 1 percent biotite phenocrysts in a tuffaceous matrix. It contains alternating bands of crystal-bearing and crystal-poor tuff. Locally, it contains rounded lithic fragments 1 $\mathrm{cm}$ or less in diameter. The unit displays rare alteration of feldspar phenocrysts to sericite or clay, and is not known to be significantly mineralized. The main exposure of this unit lies about $10 \mathrm{~km}$ north of Ladue River where it is apparently on the order of 1,000 m thick; however, we mapped isolated occurrences (or its intrusive equivalent, $P_{E} f p$ ) farther west at the Oreo Mountain porphyry copper-molybdenum prospect and along the Taylor Highway. The magnetic susceptibility varies between 0.024 and $6.59 \times 10^{-3}$ SI, and averages at $2.4 \times 10^{-3} \mathrm{SI}$. Unit PEr is geochemically distinctive in that many samples contain high yttrium (40-100 ppm; see chapter E). The age of this unit is constrained by a U-Pb zircon age of $58.9 \pm 1.4 \mathrm{Ma}$ (sample 19AW256; Wildland and others, 2021). Sanidine from a welded tuff from this unit yielded a 57.8 $\pm 3.4 \mathrm{Ma} \mathrm{K}-$ Ar age (Foster and others, 1976, recalculated by Wilson and others, 2015).

IKfv FELSIC VOLCANIC ROCKS (LATE CRETACEOUS)_Silicic tuff, porphyritic rhyolite and dacite, and lesser silicic volcaniclastic rocks and breccias. Pale to dark gray with tints of green or blue, weathering to pale, greenish, or reddish brown. Silicic tuff has sericitized feldspar phenocrysts up to $15 \mathrm{~mm}$ long (up to 20 percent), fragmented quartz (10 percent), chlorite (5 percent), biotite (5 percent), opaque minerals, and lithic clasts as large as $45 \mathrm{~mm}$ in diameter (up to 10 percent). Matrix is aphanitic or tuffaceous. Lithic fragments include metamorphic rocks, and the matrix contains flattened pumice fragments. The rocks display weak alteration. Magnetic susceptibility of this unit varies greatly between lithologies, ranging from 0.027 to $23.64 \times 10^{-3} \mathrm{SI}$ and averaging $2.90 \times 10^{-3} \mathrm{SI}$. The volcanic rocks of this unit in the map area reach upwards of $250 \mathrm{~m}$ thick and are concentrated mostly in the valley of the East Fork of the Dennison Fork of the Fortymile River. A volcaniclastic conglomerate assigned to this unit yielded a detrital zircon MDA of $65.8 \pm 1.9 \mathrm{Ma}$ (19ET330; table 2; Twelker and O'Sullivan, 2021b); more broadly, the age of this unit is also constrained by its depositional relationship above the mid-Cretaceous West Fork felsic tuff (Kwff) and by inferred correlation to the Upper Cretaceous volcanic rocks in the adjacent Northeast Tanacross geologic map (Wypych and others, 2021) and to the Carmacks volcanic rocks in Yukon (Yukon Geological Survey, 2019).

IKav ALKALINE VOLCANIC ROCKS (LATE CRETACEOUS)_Porphyritic basaltic trachyandesite to trachydacite lava flows, tuffs and lesser volcaniclastic rocks and breccias. The volcanic flows are gray, pale gray, green-gray, reddish-brown, and maroon, weathering maroon, or brown, with up to 10 -mm-long phenocrysts and 20-mm-diameter lithic fragments in aphanitic matrix. The phenocrysts are composed of plagioclase (up to 25 percent), orthopyroxene (up to 25 percent), clinopyroxene (up to 15 percent), biotite (up to 5 percent), magnetite (up to 5 percent), other opaque minerals (up to 5 percent), hornblende (up to 3 percent), and local muscovite. The trachydacite lithologies have up to 5 percent quartz, whereas the basaltic trachyandesites have up to 5 percent olivine. Plagioclase and orthopyroxene are commonly twinned. Mafic minerals are often altered. Pyroxenes have opaque mineral inclusions, are altered to amphibole and chlorite in very fine-grained matrix and are often recrystallized. Some samples contain aligned feldspar laths and hints of flow banding. Rare, disseminated pyrite and vein mineralization are 
present. The unit is characterized by higher magnetic susceptibility than the surrounding rocks, ranging from 0.028 to $52.3 \times 10^{-3} \mathrm{SI}$ and averaging $10.35 \times 10^{-3} \mathrm{SI}$. This unit is interpreted to stratigraphically overlie sedimentary unit $\mathrm{GrKs}$; it is relatively thin, having an estimated thickness of no more than 100 m. It outcrops to the east and south of Mount Fairplay. We interpret this unit to be Late Cretaceous, based on similarities in geochemical composition to other Late Cretaceous alkalic suites, compositional similarities to the Late Cretaceous Carmacks volcanic suite in Yukon (Yukon Geological Survey, 2019), and our observation that it overlies mid-Cretaceous West Fork felsic tuff (unit Kwff).

Kwff WEST FORK FELSIC TUFF (MID-CRETACEOUS)— Rhyolite to dacite tuffs and subordinate rhyolite to dacite flows over a large (ca. 500-sq-km) volcanic field in the northwestern corner of the map area. Unit is predominantly light tan, with lesser gray, pale green, pale yellow, or maroon; it weathers brown, orange, or greenish maroon. Tuffaceous lithologies are matrix-supported, moderately sorted, crystal rich, and contain up to 10 percent lithic fragments up to $50 \mathrm{~mm}$ in diameter. The crystal fraction is euhedral to fragmented. Mineralogy commonly includes around 3 percent quartz, locally up to 25 percent; around 6 percent feldspar, locally up to 15 percent; biotite is present in some samples (2 percent), and hornblende occurs rarely. Other minerals include disseminated pyrite and hematite. Lithic fragments consist of very fine-grained, subangular volcanic rocks, flattened pumice fragments, and lapilli. Volcanic flow lithologies are locally laminated and are typically porphyritic, having around 3 percent (locally up to 30 percent) feldspar phenocrysts, 1 to 2 percent quartz phenocrysts, and 1 to 3 percent disseminated, oxidized pyrite, 1 percent hematite, and up to 90 percent aphanitic groundmass. Pyrite mineralization and argillic or sericitic alteration were observed locally. This unit has a low magnetic susceptibility, ranging from 0.02 to $8.96 \times 10^{-3}$ SI and averaging $1.51 \times 10^{-3}$ SI. A sample of tuff yielded a $107.9 \pm 2.2 \mathrm{Ma}$ zircon crystallization age (19TJN299; Wildland and others, 2021). Bacon and others (1990) interpreted this unit as one of several remnant volcanic calderas in the region.

Kmv VOLCANIC ROCKS OF MCARTHUR CREEK AREA (CRETACEOUS)—Small trachydacite to rhyolite volcanic flows and lesser breccias and ash falls occurring in the upper McArthur Creek drainage. Volcanic flows are porphyritic, with some flow banding. Phenocrysts, up to 3-mm long, include up to 15 percent plagioclase, 10 percent hornblende, and 3 percent quartz. Up to 10 percent secondary opaque minerals, probably magnetite, replace hornblende. Groundmass is very fine-grained devitrified glass. Ash falls are tuffaceous, lithic rich, and pumice rich. Subrounded lithic clasts are of volcanic material. Matrix is altered, with rare, fragmented quartz phenocrysts, some completely chloritized mafic minerals and secondary biotite clots. The rock is highly altered or weathered, with pumice fragments partially or completely weathered out. Average magnetic susceptibility of this unit is $1.20 \times 10^{-3} \mathrm{SI}$ but varies between 0.02 and $4.62 \times 10^{-3}$ SI. The maximum age of this unit is constrained by its deposition on the exhumed mid-Cretaceous granodiorite batholith (unit Kgd; 100-108 Ma [Wildland and others, 2021]).

\section{Paleogene intrusive rocks}

PEfp FELSIC PORPHYRY (PALEOGENE) —Dikes and small intrusions of felsic porphyry and lesser granite. Dikes contain up to 6-mm phenocrysts in an aphanitic or fine-grained matrix. The phenocrysts include 2 to 20 percent quartz, up to 10 percent feldspar, 5 percent muscovite, 3 percent plagioclase, 3 percent magnetite, 2 percent opaque minerals, and 1 percent biotite. Matrix is aphanitic, glassy (50 to 100 percent devitrified), and in some cases recrystallized. Phenocrysts are euhedral to subhedral; quartz is slightly resorbed and often fractured, and feldspars are altered to sericite. The less abundant equigranular to porphyritic granite is fine- to medium-grained, and has 50 to 70 percent feldspar, 25 to 45 percent quartz, and about 5 percent biotite. Symplectite textures are observed in the fine-grained matrix. Some samples have sparse disseminated or veinlet-hosted pyrite, and vuggy quartz veins with disseminated pyrite weathering to iron oxides. Magnetic susceptibility of this unit varies between 0.005 and 5.35, with an average of $1.36 \times 10^{-3} \mathrm{SI}$. Zircons from two samples of this unit yielded ages of $57.1 \pm 1.2$ and 58.6 
$\pm 1.4 \mathrm{Ma}$ (samples $18 \mathrm{KS} 100$ and 19ET277; Wildland and others, 2021). The equivalent unit in Yukon, the North Ladue River porphyry, yielded a U-Pb zircon age of 58.3 $\pm 0.5 \mathrm{Ma}$ (Yukon Geological Survey, 2020). This unit is of similar age and geochemistry to unit PEr (see chapter E) and we interpret it to be the intrusive equivalent of that unit. We mapped unit PEfp in the Pushbush copper-molybdenum prospect area, where it is barren and apparently postdates mineralized mid-Cretaceous granite (see chapter F). This unit occurs at the Oreo Mountain copper-molybdenum prospect as post-mineralization rhyolite dikes intercepted in drilling (Kennecott Exploration, 2019; see chapter F).

\section{Late Cretaceous intrusive rocks}

IKfd FELSIC DIKES (LATE CRETACEOUS)—Granite porphyry dikes, some of which are hydrothermally altered. The dikes contain 1-3 mm phenocrysts of alkali feldspar (5-10 percent), quartz (0-10 percent), altered plagioclase (5-10 percent), and biotite (0-5 percent, mostly altered to chlorite) in an aphanitic matrix consisting of very fine-grained quartz, sericite, and feldspar. Pyrite and/or tourmaline are locally present as veinlets or disseminated replacements. Magnetic susceptibility is low $\left(0.03-5 \times 10^{-3} \mathrm{SI}\right.$, average $0.8 \times 10^{-3} \mathrm{SI}$ ) reflecting their felsic nature and extensive hydrothermal alteration. A sample of this unit yielded a U-Pb zircon crystallization age of 70.5 $\pm 1.6 \mathrm{Ma}(19 \mathrm{RN} 359$; Wildland and others, 2021).

IKma MAFIC ALKALINE DIKES (LATE CRETACEOUS?)—Low-quartz dikes with compositions plotting in the alkali basalt field. Based largely on hand-held XRF data, samples range from alkali gabbro to monzonite with porphyritic to sub-equigranular textures. Feldspar (10-50 percent) is an essential component; mafic minerals are generally altered and include variable combinations of clinopyroxene, hornblende, and biotite. Abundant epidote (5-25 percent) is an important alteration mineral along with albite and calcite. Magnetic susceptibility is highly variable $\left(0.6-58 \times 10^{-3} \mathrm{SI}\right)$, but commonly high (average $14 \times 10^{-3} \mathrm{SI}$ ) reflecting both primary igneous character and subsequent hydrothermal alteration. Age assignment is based on proximity of many of the dikes to the Mount Fairplay igneous complex and similarity in chemical composition; this unit also crosscuts the main body of unit $1 \mathrm{Kgqm}$ at Mount Fairplay and must therefore be Late Cretaceous or younger.

IKgd GRANODIORITE TO GRANITE (LATE CRETACEOUS)—Dikes and stocks of fine- to medium-grained granodiorite to granite. Holocrystalline variants are porphyritic, seriate, or equigranular, with grain size ranging from 0.1 to $25 \mathrm{~mm}$. Mineralogy includes 10 to 55 percent plagioclase, 1 to 25 percent hornblende, up to 25 percent quartz and alkali feldspar, 0.5 to 18 percent biotite, 1 to 6 percent magnetite, and up to 1 percent secondary chlorite. Porphyry intrusions have an aphanitic, locally amygdaloidal groundmass, and up-to-10-mm phenocrysts including plagioclase (1 to 15 percent), hornblende (up to 5 percent), biotite ( 2 percent), clinopyroxene ( 2 percent), quartz ( 2 percent). Alteration includes sericitized feldspars, quartz-tourmaline veinlets and disseminated tourmaline, quartz-sulfide veinlets, and disseminated pyrite. At the Oreo Mountain prospect, alteration includes potassic assemblages including secondary biotite and potassium feldspar associated with quartz sulfide veins (see chapter F). The magnetic susceptibility of this unit is between 0.03 and $62.04 \times 10^{-3} \mathrm{SI}$, averaging $7.13 \times 10^{-3} \mathrm{SI}$. Three samples have been dated using U-Pb methods: a sample collected just south of Big Creek yielded 69.3 $\pm 1.4 \mathrm{Ma}$ (19WCW037), and two samples from Oreo Mountain porphyry prospect yielded $71.4 \pm 1.4$ and $72.1 \pm 1.6 \mathrm{Ma}(19 \mathrm{TJN} 243$ and 19RN282; table 1; Wildland and others, 2021).

IKpg PORPHYRITIC GRANITE (LATE CRETACEOUS)—A fault-bounded intrusion of porphyritic granite exposed west of the Oreo Mountain porphyry prospect. Porphyritic, hypidiomorphic, and characterized by large, sub- to euhedral alkali feldspar phenocrysts up to 20 -mm-long. The phenocrysts have biotite and titanite inclusions. The matrix comprises 1- to 5-mm-long minerals: up to 40 percent plagioclase, 10 to 20 percent quartz, up to 15 percent hornblende, 10 to 12 percent biotite, up to 3 percent 
magnetite, 3 percent titanite, and up to 5 percent secondary chlorite. Plagioclase has perthitic exsolution and is partially to highly sericitized, euhedral to subhedral quartz displays undulatory extinction, subhedral hornblende is chloritized, biotite is slightly chloritized and has zircon inclusions. Secondary chlorite forms clots near biotite and hornblende. The unit has an average magnetic susceptibility of $9.17 \times 10^{-3}$ SI, which may vary between 0.31 to $19.64 \times 10^{-3} \mathrm{SI}$. A sample of the porphyritic granite yielded a U-Pb zircon crystallization age of $68.8 \pm 1.5 \mathrm{Ma}$ (19RN287; table 1; Wildland and others, 2021).

\section{Late Cretaceous intrusive rocks of the Mount Fairplay complex}

As described in the detailed petrological studies of the area (Kerin, 1976; Newberry, 2020), the Mount Fairplay igneous complex comprises two major rock groups: (1) those containing normative feldspathoids or little to no quartz, and (2) those containing significant quartz. The former group, the alkalic group, includes monzonite $(\mathrm{lKm})$, syenite (lKsy), and rare alkali-feldspar syenite (lKafs); the latter, sub-alkalic group, comprises quartz monzonite and granite $(\mathrm{Kgqm})$. The quartz-rich and quartz-poor rocks both contain relatively anomalous thorium (Th; greater than $30 \mathrm{ppm}$ ), are closely coeval, and both contain diopsidic clinopyroxene. For these reasons, the alkalic and subalkaline rocks of the Mount Fairplay complex appear to be related. For additional results of our work at Mount Fairplay please refer to Newberry (2020).

IKgqm GRANITE AND QUARTZ MONZONITE (LATE CRETACEOUS) —A small (approximately $10-\mathrm{sq}-\mathrm{km}$ ) body that constitutes the core of the Mount Fairplay igneous complex. The body is mostly diopside-hornblende-biotite granite, but locally (with lower quartz content) diopside-hornblende-biotite quartz monzonite. Both types are usually fine-to medium-grained, sub-equigranular to porphyritic, with alkali feldspar (25-40 percent) up to $15 \mathrm{~mm}$. Dikes are all porphyritic. Quartz (10-30 percent) is usually $0.5-1 \mathrm{~mm}$, interstitial, and difficult to recognize in hand specimen. Plagioclase (30-40 percent, $1-4 \mathrm{~mm})$ is variably altered to sericite. Diopsidic clinopyroxene (1-10 percent, $0.2-0.5 \mathrm{~mm})$ is surrounded by hornblende (3-10 percent, $0.5-1 \mathrm{~mm}$ ) and (or) biotite (5-12 percent, $0.5-2 \mathrm{~mm}$ ) such that only biotite is readily visible in hand specimen. Minor minerals include 1-2 percent (mostly secondary?) titanite, $0.5-2$ percent (mostly primary?) magnetite, and 0.2-0.5 percent primary ilmenite. Magnetic susceptibility $\left(3 \times 10^{-3} \mathrm{SI}\right.$, average $\left.7 \times 10^{-3} \mathrm{SI}\right)$ is lower than that of the alkalic units (1Kafs, $\left.1 \mathrm{Km}, 1 \mathrm{Ksy}\right)$ and reflected in the low aeromagnetic signature for this unit (Emond and others, 2015). Dusel-Bacon and others (2015) determined a U-Pb SHRIMP zircon age of 66.5 \pm 1.1 Ma for this unit. Kerin (1976) noted textural evidence that this body is slightly younger than the enclosing syenite (unit $\mathrm{KKsy}$ ). Although this unit plots as subalkaline on a total alkali vs. silica diagram (Newberry, 2020), the presence of diopsidic clinopyroxene (similar in composition to such from alkaline phases of the body), proximity to the alkaline phases, and similarity in age, indicate that this body is broadly related to the enclosing, more alkalic parts of the Mount Fairplay complex.

ALKALI FELDSPAR SYENITE (LATE CRETACEOUS)—A small (less than 1-sq-km), dike-like body representing the most-fractionated of the alkalic rocks of the Mount Fairplay complex. Rocks from this unit have the highest uranium (U), Th, and rare earth element (REE) concentrations seen in the complex (Newberry, 2020). The rocks are fine- to medium-grained with 85-95 percent alkali feldspar (1-4 mm), 3-10 percent albitic plagioclase (1-2 mm), 0-3 percent quartz $(0.5-1 \mathrm{~mm}), 3-7$ percent biotite $(1-2 \mathrm{~mm})$, and $0-3$ percent hornblende $(0.3-1 \mathrm{~mm})$. Minor to trace minerals include titanite (secondary?), magnetite, fluorite (secondary?), and ilmenite. Plagioclase is commonly altered to sericite and biotite is extensively altered to chlorite. Magnetic susceptibility is highly variable, $1-32 \times 10^{-3} \mathrm{SI}$ (averaging $10 \times 10^{-3} \mathrm{SI}$ ) and reflects the variable magnetite content. The body has a dike-like shape and, based on chilled contacts, Kerin (1976) concluded that it intrudes other alkalic units (lKafs, lKm, IKsy). 
IKsy SYENITE (LATE CRETACEOUS)_An arcuate body that comprises the majority of the alkalic rocks of the Mount Fairplay igneous complex. It surrounds and is locally intruded by the central granite-quartz monzonite (Kerin, 1976). The three textural varieties include: medium- to coarsely porphyritic that comprises the majority of the unit; syenite pegmatite (confined to the northwest corner of the complex), which contains alkali feldspar crystals 5-10 cm long; and fine- to medium-grained porphyritic phases (confined to the southern margin of the complex), which contain 5-mm-long alkali feldspar crystals in a 0.5-2 mm matrix. The different textural types are mineralogically similar: 50-60 percent alkali feldspar (5-100 $\mathrm{mm}$ long), $15-25$ percent plagioclase $(0.5-2 \mathrm{~mm}), 0-1$ percent quartz $(0.3-0.5 \mathrm{~mm}), 15-20$ percent mafic minerals $(0.5-1.5 \mathrm{~mm}), 0.5-1$ percent apatite (less than $0.5 \mathrm{~mm}), 1-2$ percent magnetite $(0.2-0.5 \mathrm{~mm}), 0.5-1$ percent ilmenite $(0.1-0.3 \mathrm{~mm})$, and $0.5-1$ percent (secondary?) titanite. The mafic minerals commonly occur as multi-mineral aggregates, cored by calcium $(\mathrm{Ca})$-rich clinopyroxene $(2-7$ percent) that is usually surrounded by biotite (5-12 percent) and in turn surrounded by hornblende (1-5 percent). Texturally secondary chlorine $(\mathrm{Cl})$-rich biotite and (or) hornblende constitute up to one quarter of the mafic minerals (Newberry, 2020). Plagioclase is commonly altered; typically to sericite, locally to Cl-rich scapolite. Magnetic susceptibility is high (7-35 x $10^{-3} \mathrm{SI}$, average $\left.17 \times 10^{-3} \mathrm{SI}\right)$ and responsible for a significant aeromagnetic anomaly (Emond and others, 2015). This unit intrudes the 67 Ma monzonite $(1 \mathrm{Km})$ and is intruded by the $66.5 \mathrm{Ma}$ quartz monzonite $(\mathrm{Kgqm})$. Mount Fairplay igneous complex. Based on textural relations, it is the earliest intrusion in the complex (Kerin, 1976) and is the only unit that contains olivine $\left(\mathrm{Fa}_{63-74} ;\right.$ Newberry, 2020). Usually medium-grained, sub-equigranular, but also coarse porphyritic with alkali feldspar up to $3 \mathrm{~cm}$ in a medium-grained matrix. Minerals include 35-45 percent plagioclase $(1-4 \mathrm{~mm}), 30-40$ percent alkali feldspar (4-50 $\mathrm{mm}), 0-2$ percent quartz $(0.3-0.5 \mathrm{~mm}), 25-35$ percent mafic minerals (typically multi-mineral aggregates $1-3 \mathrm{~mm}), 1-2$ percent apatite $(0.3-0.5 \mathrm{~mm}), 1-3$ percent magnetite $(0.5-1 \mathrm{~mm}), 1$ percent ilmenite $(0.5 \mathrm{~mm})$, and $0-3$ percent (secondary?) titanite $(0.5-1 \mathrm{~mm})$. Unaltered olivine $(0-3$ percent, $0.3-0.7 \mathrm{~mm}$ ) occurs as inclusions in biotite (5-15 percent, $1-2 \mathrm{~mm}$ ); otherwise, former olivine occurs as fine-grained, hematite-quartz intergrowths. In either case, like clinopyroxene, it is invisible in hand specimen. Ca-rich clinopyroxene (4-7 percent, $0.5-1 \mathrm{~mm}$ ) is invariably surrounded by biotite and (or) hornblende (10-20 percent, $0.5-1.5 \mathrm{~mm})$ and is partly altered to actinolitic amphibole. Biotite is variably altered to chlorite and plagioclase to sericite and (or) epidote. Magnetic susceptibility is very high (8-48 x $10^{-3} \mathrm{SI}$, averaging $\left.25 \times 10^{-3} \mathrm{SI}\right)$ reflecting its significant magnetite content. The absolute age of this unit is constrained by a U-Pb zircon SHRIMP age of $67 \pm 1.5 \mathrm{Ma}$ (Dusel-Bacon and others (2015).

\section{Mid-Cretaceous intrusive rocks}

Kgp GRANITE PORPHYRY (MID-CRETACEOUS)—Dikes and stocks of granite porphyry and porphyritic granite generally concentrated in southwest quadrant of the map area south of Mount Fairplay. Grain sizes range from 0.001 to $12 \mathrm{~mm}$ depending on lithology. The most common lithologies are porphyry and porphyritic granite; these have an aphanitic to fine-grained matrix and phenocrysts (up to $10 \mathrm{~mm}$ ) composed of up to 40 percent quartz, 35 percent plagioclase, 10 percent hornblende, and 10 percent biotite. Accessory minerals include tourmaline, rutile, allanite, and secondary sericite, chlorite, and pyrite. Quartz is partially resorbed, sub- to euhedral, plagioclase is partially to completely sericitized, biotite is slightly to completely chloritized and hornblende is altered to chlorite and epidote. The aphanitic groundmass is devitrified; some samples are completely recrystallized to a mixture of feldspar and quartz, and some contain spherulites. Minor propylitic, sericitic and argillic alterations are present, with disseminated pyrite, iron oxides replacing pyrite, and sparse, hairline quartz veinlets. The magnetic susceptibility of this unit depends on the amount of weathering and alteration and varies between 0.006 
and $9.81 \times 10^{-3} \mathrm{SI}$, averaging $1.13 \times 10^{-3} \mathrm{SI}$. Four samples returned U-Pb zircon ages ranging from ca. 107 to $115 \mathrm{Ma}$ (Wildland and others, 2021). Dikes of this unit intrude both parautochthonous and allochthonous metamorphic units and post-date mid-Cretaceous granite $(\mathrm{Kg})$ and granodiorite $(\mathrm{Kgd})$.

Kmd MAFIC-INTERMEDIATE ALKALINE DIKES (MID-CRETACEOUS)_Basalt, basaltic trachyandesite, and trachyandesite dikes and small plugs intruding into the granodiorite batholith (unit $\mathrm{Kgd})$. Porphyritic, with aphanitic groundmass and up to 10-mm-long phenocrysts of euhedral plagioclase (5 percent), biotite (5 percent), and locally, resorbed quartz phenocrysts (up to 15 percent). Plagioclase is sericitized, biotite is largely chloritized, and hornblende is skeletal, partially altered to chlorite and secondary calcite (up to 15 percent). Up to $2 \mathrm{~mm}$ long secondary calcite crystallize in small, up to 10 -mm-diameter cavities. Groundmass is either devitrified glass or very fine-grained feldspar \pm quartz and biotite. The magnetic susceptibility varies between 0.03 and $25.78 \times 10^{-3} \mathrm{SI}$ and averages $7.19 \times 10^{-3}$ SI. Zircon from this unit yielded an age of $100.3 \pm 2.2 \mathrm{Ma}$ (Wildland and others, 2021). Joyce (2002) documents similar dikes at the Longline gold prospect in the adjacent Yukon. MAFIC TO INTERMEDIATE DIKES (MID-CRETACEOUS)_Basaltic andesite to andesite dikes and small intrusions in the granodiorite batholith (unit Kgd) in McArthur Creek area. Porphyritic, with aphanitic to fine-grained matrix, and up to 20-mm-long phenocrysts. Phenocrysts comprise up to 20 percent plagioclase, 20 percent hornblende, 15 percent quartz, 10 percent biotite, 5 percent magnetite, accessory allanite, and secondary chlorite. Plagioclase is sericitized, quartz is resorbed on the edges, hornblende is partially chloritized and, in some samples, skeletal, and biotite is highly altered to chlorite. The fine-grained groundmass is composed mostly of sericitized plagioclase with lesser quartz and hornblende. Some samples are veined and brecciated, and a few rocks have propylitic overprinting, some possible potassic alteration, and disseminated pyrite, chalcopyrite, and sparse quartz veinlets. Magnetic susceptibility varies between 0.02 and $19.58 \times 10^{-3} \mathrm{SI}$, with an average of $2.43 \times 10^{-3} \mathrm{SI}$. An andesite dike yielded a U-Pb zircon age $102.8 \pm 2.2 \mathrm{Ma}$, and a porphyry sampled at the nearby Pushbush prospect yielded a U-Pb zircon age of $110.7 \pm 2.5 \mathrm{Ma}$ (Wildland and others, 2021). Joyce (2002) documents similar dikes at the Longline gold prospect in the adjacent Yukon.

Kgd GRANODIORITE (MID-CRETACEOUS)_Batholith and plutons of granodiorite and lesser granite occupying more than $500 \mathrm{sq} \mathrm{km}$ in the southeast quadrant of the map. Unit is typically equigranular to seriate, hypidiomorphic, and less commonly porphyritic; locally the granodiorite is strained and is best described as orthogneiss. Grain size varies from 0.1 to $20 \mathrm{~mm}$. Mineralogy consists of 25 to 60 percent plagioclase, 10 to 45 percent quartz, up to 25 percent orthoclase, 15 to 20 percent microcline, 5 to 15 percent biotite, 1 to 19 percent hornblende, up to 2 percent augite, 2 percent magnetite, and trace titanite. 1 to $4 \mathrm{~mm}$ diameter interstitial quartz in some samples displays undulose extinction and can form granoblastic aggregates. Plagioclase is commonly zoned, up to $5 \mathrm{~mm}$ long, and partially sericitized; microcline is either interstitial or euhedral. Both biotite and hornblende are locally partially chloritized, and hornblende is locally partially replaced by epidote. Biotite forms rims on hornblende and augite, where present. The rocks are weakly altered to propylitic or sericitic assemblages. Most of the unit has no mineralization; however, unit Kgd granodiorite hosts polymetallic vein mineralization in the Moosehorn area (Honks, Move, and Goodrich Porphyry prospects; see chapter F). The local predominance of gneissic textures and the undulose extinction and granoblastic textures of quartz suggest this unit was emplaced prior to the end of Early Cretaceous regional ductile deformation. Magnetic susceptibility of this unit varies between 0.03 and $39.63 \times 10^{-3} \mathrm{SI}$ and averages $5.51 \times 10^{-3} \mathrm{SI}$. U-Pb zircon dating yielded ages of $104.2 \pm 2.3$ and $107.7 \pm 2.3 \mathrm{Ma}$ (Wildland and others, 2021); the apparently correlative Silver Creek Granodiorite (unit Khgd) from the adjacent Alaska Highway Corridor geologic map (Solie and others, 2019) yielded ages between ca. 97 and $103 \mathrm{Ma}$ (Solie and others, 2014). 
Kgb GABBRO TO DIORITE (MID-CRETACEOUS)_One or more small plugs or dikes of hornblende gabbro to diorite, possibly grading into the adjacent granite and comprising a zoned intrusive complex. Rocks of this unit are granophyric, equigranular, and have grain size varying between 1 and $10 \mathrm{~mm}$. Unit is composed of 40 to 70 percent plagioclase, 7 to 60 percent euhedral to anhedral hornblende, up to 20 percent anhedral quartz, up to 15 percent subhedral biotite, up to 20 percent anhedral alkali feldspar, ilmenite and magnetite and secondary actinolite, chlorite, epidote and sericite. Plagioclase is interlocking, strongly zoned and slightly sericitized. Up to $10-\mathrm{mm}$-long hornblende is poikilitic, with plagioclase inclusions and partially altered to biotite or actinolite. Biotite is primary as well as secondary, and is altered to chlorite, epidote and titanite. Interstitial quartz has moderate undulose extinction. No mineralization was noted. The magnetic susceptibility depends on magnetite composition of the rock and varies between 0.30 and $11.05 \times 10^{-3} \mathrm{SI}$ and averages $4.13 \times 10^{-3} \mathrm{SI}$. Unit yielded a U-Pb zircon age of $108.1 \pm 2.3 \mathrm{Ma}$ (Wildland and others, 2021). The equivalent of this unit in the Alaska Highway Corridor Map (unit Kgb) yielded a zircon age of $103.8 \pm 2.7 \mathrm{Ma}$ (Solie and others, 2014) and an ${ }^{40} \mathrm{Ar} /{ }^{39} \mathrm{Ar}$ age on biotite is slightly younger at $100.4 \pm 3.2 \mathrm{Ma}$ (Solie and others, 2013).

Kg GRANITE (MID-CRETACEOUS)_Biotite-bearing peraluminous granite stocks and intrusions, with aplite and pegmatite dikes of similar composition. Granite is tan, cream, or light gray to pale pink, seriate to equigranular, hypidiomorphic, with grain size between 0.1 and $35 \mathrm{~mm}$. Typically the granite has up to up to 60 percent subhedral alkali feldspar, 30 percent plagioclase, 35 percent quartz, 10 percent biotite, 3 percent primary white mica, accessory tourmaline, rutile and zircon and secondary chlorite, sericite, and clay minerals. The alkali feldspar is mostly orthoclase, albite is zoned, plagioclase is sericitized. Some of the interstitial quartz is recrystallized to form granoblastic aggregates and has undulose extinction. Biotite is partially chloritized, is intergrown with muscovite, and has abundant zircon damage zones. Locally altered to clay and chlorite but is generally fresh with rare veins of pyrite.

Pegmatite dikes are similar in composition to the granite, with up to 50-mm-long euhedral orthoclase and microcline crystals in a matrix of about 10 -mm-diameter quartz and plagioclase. Thin books of biotite between 50 and $70 \mathrm{~mm}$ in diameter are found irregularly throughout the rock. Biotite is slightly chloritized on margins and forms up to 5 percent of the rock.

Aplite dikes are light gray and equigranular, with grain sizes between 0.5 and $2 \mathrm{~mm}$. Mineralogy is similar to the larger granitic intrusions and includes rare metamorphic xenoliths. Locally altered with up to 1 percent disseminated pyrite, sparse quartz veinlets, sericite, and local tourmaline clots (up to 0.1 percent). The granites, pegmatites, and aplites are characterized by low magnetic susceptibility, ranging between 0 and 1.5 and averaging $0.3 \times 10^{-3}$ SI. Five samples of this unit from within the map area yielded U-Pb zircon ages ranging from 106.7 to $112.8 \mathrm{Ma}$ (Wildland and others, 2021). Equivalent granite and pegmatite (unit $\mathrm{Kg}$ ) in the adjacent Northeast Tanacross geologic map yielded a zircon $\mathrm{U}-\mathrm{Pb}$ age of $114.1 \pm 1.4 \mathrm{Ma}$ (Wypych and others, 2020) and ${ }^{40} \mathrm{Ar} /{ }^{39} \mathrm{Ar}$ ages ranging from ca. 105 to $110 \mathrm{Ma}$ (Naibert and others, 2018). On the eastern edge of the Tanacross Quadrangle, the granite extends into Yukon, Canada, where it is mapped as the ca. 110-109 Ma Crag Mountain pluton, part of the Whitehorse Plutonic Suite (Yukon Geological Survey, 2019). The granite has similar age and composition to other granites in the Yukon such as the Dawson Range batholith, the Coffee Creek granite, and the Moosehorn Range granitoids (Allan and others, 2013).

\section{METAMORPHIC ROCKS Allochthonous rocks of the Seventymile terrane}

SERPENTINITE (TRIASSIC-MISSISSIPPIAN) - Two bodies of greenschist-facies, mostly ultramafic rock occurring at the boundary between rocks of the parautochthonous Lake George assemblage 
and those of the allochthonous terranes, suggesting that this unit is part of a suture zone between these different tectonic assemblages. Unit consists of predominantly fine- to medium-grained meta-dunite and meta-clinopyroxenite, but likely includes some metamafic rock and may include tectonic slivers of other rock types. Serpentinite (meta-dunite) is $90-95$ percent serpentine $(0.05-0.2 \mathrm{~mm}), 0-5$ percent dolomite and magnesite $(0.05-0.1 \mathrm{~mm}), 0.5-5$ percent Cr-magnetite $(0.02-0.3 \mathrm{~mm})$, and $1-5$ percent chlorite $(0.05-0.1 \mathrm{~mm})$. Meta-clinopyroxenite (tremolite-chlorite rock) is $65-85$ percent randomly oriented tremolite needles $(0.4-2 \mathrm{~mm}), 15-30$ percent chlorite $(0.2-0.5 \mathrm{~mm}), 0.5-1$ percent ilmenite $(0.05 \mathrm{~mm})$, and $0.5-2$ percent magnetite $(0.05-0.1 \mathrm{~mm})$, and $0-7$ percent albite $(0.5-1 \mathrm{~mm})$. These minerals, and the lack of other diagnostic metamorphic minerals, were confirmed by microprobe. Magnetic susceptibility is extremely variable $\left(0.2-247 \times 10^{-3} \mathrm{SI}\right.$, average $\left.59 \times 10^{-3} \mathrm{SI}\right)$, reflecting the rock type variability. The age of this unit is based on our interpretation that it belongs to the Seventymile terrane, which includes Mississippian to Upper Triassic sedimentary rocks (Foster and others, 1994).

\section{Allochthonous metamorphic rocks of the Klondike assemblage}

The Klondike assemblage is exposed along the eastern edge of the map area adjacent to the Alaska-Yukon border. The contact of the Klondike assemblage units with other allochthonous Yukon-Tanana Terrane units is interpreted as one or more low-angle faults due to abrupt change in metamorphic grade between the greenschist-facies Klondike assemblage and the amphibolite-facies Ladue River area units (see chapter B). The Klondike units are also in low-angle fault contact with the parautochthonous Lake George assemblage. Faults at the base of the Klondike are intruded by small Cretaceous granite $(\mathrm{Kg})$ plutons, indicating that faulting occurred prior to the mid-Cretaceous. Late Cretaceous and Paleogene volcanic units sit unconformably on top of the Klondike assemblage in the eastern part of the map area, indicating the Klondike assemblage has been at the surface since the Late Cretaceous without significant regional erosion or deformation. This assemblage is mapped across the border in Yukon, where it overlies rocks of the Snowcap assemblage or the Finlayson assemblage (Gordey and Ryan, 2005; Ryan and others, 2013).

The age of this assemblage is based on felsic schist samples yielding Permian zircon ages (Jones and O'Sullivan, 2020; Wildland and others, 2021). Felsic schist is a minor lithology in Pks in our map area, and we interpret these layers as depositionally interlayered felsic volcanic rocks. It is possible that the dated rocks are metamorphosed intrusions. Nevertheless, we feel justified in correlating these rocks with the Klondike assemblage of Gordey and Ryan (2005) in the adjacent Stewart River area of Yukon.

Pks SCHIST (PERMIAN)—A mixed unit consisting of chlorite schist, muscovite schist, and semischist of mixed sedimentary and volcanic protoliths, as well as minor felsic schist interpreted as metarhyolite. Unit also contains minor quartzite, porphyroclastic orthogneiss, and rare metaconglomerate. Outcrops are generally pale green to dark green to gray and grain size ranges from 0.1 to $2 \mathrm{~mm}$, locally with phenocrysts in the metarhyolite unit up to $10 \mathrm{~mm}$. Unit is schistose, crenulated on the sub-cm scale, and the dominant foliation is often folded at the decimeter to meter scale. Greenschist-facies mineralogy and the relatively fine-grained, schistose texture suggest that this unit never reached amphibolite-facies conditions experienced by the other metamorphic rocks in the map area. Mineralogy includes 30-60 percent quartz, up to 40 percent actinolite, up to 40 percent albite, up to 15 percent muscovite, up to 15 percent biotite, up to 10 percent chlorite, and up to 5 percent epidote. Schists are locally iron stained and contain traces of pyrite along fracture surfaces and veinlets. Magnetic susceptibility ranges from 0.04 to $2.91 \times 10^{-3} \mathrm{SI}$, with an average of $0.89 \times 10^{-3} \mathrm{SI}$ and a median of $0.23 \times 10^{-3} \mathrm{SI}$. Felsic schist from this unit, interpreted as metarhyolite, yielded $\mathrm{U}-\mathrm{Pb}$ zircon ages of $256.7 \pm 5.8$ and $261.4 \pm 5.8 \mathrm{Ma}$ (table 1 ; Wildland and others, 2021). Jones and O'Sullivan (2020) obtained ages ranging from ca. 257 to 267 Ma from similar rocks in the area, supporting the correlation of this package to the Klondike Schist assemblage in Yukon. 
Pkgs GRAPHITIC SCHIST (PERMIAN) — A relatively thin, recessive-weathering unit distinguished by its locally significant graphite content and anomalously low resistivity that makes it easily mapped in airborne electromagnetic surveys (Burns and others, 2020a; AERODAT, 1977). Unit is dark gray to pale green, and grain size ranges from 0.1 to $5 \mathrm{~mm}$. Mineralogy includes up to 60 percent quartz, up to 40 percent plagioclase feldspar, up to 30 percent chlorite, up to 20 percent muscovite, and graphite. Diamond drilling at the Ladue Camp prospect intercepted $83 \mathrm{~m}$ of graphitic schist, including several thin bands of massive sulfide (Cities Service Minerals Corporation, 1980; see chapter F). Magnetic susceptibility has a restricted range of 0.05 to $0.25 \times 10^{-3} \mathrm{SI}$, with an average of $0.15 \times 10^{-3} \mathrm{SI}$.

Pkmb METABASITE (PERMIAN)_Dark gray to dark green schistose unit consisting of mafic to intermediate greenschist. Unit corresponds to highly magnetic bands in airborne magnetic survey (Burns and others, 2020a), which aided mapping. Mineralogy of the unit includes 40-60 percent chlorite, up to 40 percent actinolite, up to 40 percent albite, up to 10 percent epidote, up to 30 percent quartz, up to 10 percent white mica, up to 2 percent magnetite, and rare disseminated sulfides. High magnetic susceptibility ranging from 0.06 to $93.0 \times 10^{-3} \mathrm{SI}$, with an average of $13.59 \times 10^{-3} \mathrm{SI}$, and a median of $6.70 \times 10^{-3} \mathrm{SI}$.

\section{Allochthonous metamorphic rocks of the Ladue River unit}

Variably retrograded amphibolite-facies metamorphic rocks exposed along ridges surrounding the South Fork of the Ladue River are known as the Ladue River unit (Dusel-Bacon and others, 2006), although part of this unit as originally defined has been remapped as Klondike assemblage (Jones and others, 2017; this study). Metaigneous rocks of this unit crystallized during the Late Devonian to Early Mississippian; however, while some of these are clearly metaplutonic, others could have either volcanic or intrusive protoliths (fig. 3). Accordingly, the associated metasedimentary rocks could be as young as Early Mississippian or as old as Proterozoic.

The Ladue River unit has pre-Cretaceous ${ }^{40} \mathrm{Ar} /{ }^{39} \mathrm{Ar}$ cooling ages (table 3; Jones and Benowitz, 2020) that indicate it belongs to the allochthonous YTT. Beyond that, the potential regional correlations of this unit are open to debate. The quartz-rich metasedimentary rocks and relative scarcity of intercalated amphibolite layers in the Ladue River unit suggests some similarity to the pre-Mississippian Snowcap assemblage in Yukon (Colpron and others, 2006; Piercey and Colpron, 2009). The Ladue River unit contains fewer fine-grained orthogneisses and lacks the marble layers typically found in the Fortymile River assemblage
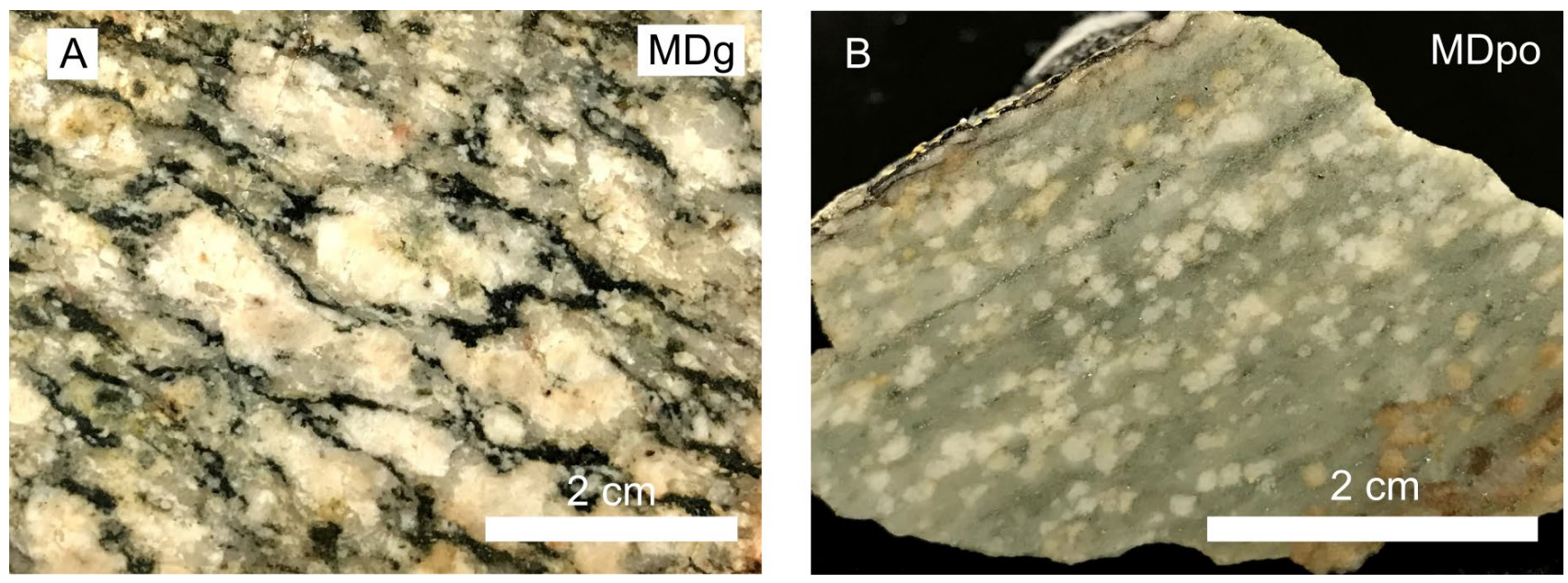

Figure 3. Hand sample photographs illustrating the textural differences between end member examples of unit MDg metagranitoid (A; sample 19RN157) and unit MDpo feldspar-porphyroclastic orthogneiss (B; sample 19ADW140). 
Table 3. Selected ${ }^{40} \mathrm{Ar} /{ }^{39} \mathrm{Ar}$ and $\mathrm{K}-\mathrm{Ar}$ ages used in the construction of this map. All ages are from Jones and Benowitz (2020) except for K-Ar age 74ASj111, which is from Foster and others (1976), recalculated in Wilson and others (2015).

\begin{tabular}{|c|c|c|c|c|c|c|c|c|}
\hline Sample & Latitude & Longitude & $\begin{array}{l}\text { Map } \\
\text { Unit }\end{array}$ & Lithology & $\begin{array}{l}\text { Sample } \\
\text { Material }\end{array}$ & $\begin{array}{c}\text { Preferred } \\
{ }^{40} \mathrm{Ar} /{ }^{39} \mathrm{Ar} \\
\text { Age }\end{array}$ & $\begin{array}{l}\text { Uncertainty } \\
\qquad(2 \sigma)\end{array}$ & $\begin{array}{l}\text { Preferred age type } \\
\text { and comments }\end{array}$ \\
\hline 14AJJ011 & 63.2035 & -141.0264 & MPlo & $\begin{array}{l}\text { biotite and } \\
\text { hornblende } \\
\text { gneiss }\end{array}$ & hornblende & 103.7 & 2.6 & $\begin{array}{l}\text { weighted average, } 1 \text { of } \\
8 \text { fractions, criteria not } \\
\text { met for plateau age }\end{array}$ \\
\hline 14AJJ019 & 63.3040 & -141.4625 & $\mathrm{MDg}$ & gneissic granite & muscovite & 253.2 & 4.4 & $\begin{array}{l}\text { weighted average, } 6 \text { of } \\
8 \text { fractions, criteria not } \\
\text { met for plateau }\end{array}$ \\
\hline 16AJJ211 & 63.34386 & -141.3678 & Pks & $\begin{array}{c}\text { leucocratic } \\
\text { quartzose } \\
\text { gneiss }\end{array}$ & muscovite & 236.1 & 2.6 & $\begin{array}{l}\text { weighted average, } 2 \text { of } \\
8 \text { fractions, criteria not } \\
\text { met for plateau }\end{array}$ \\
\hline 16AJJ216 & 63.5011 & -141.0933 & Melgs & $\begin{array}{c}\text { augen } \\
\text { orthogneiss }\end{array}$ & biotite & 111.7 & 2.4 & $\begin{array}{l}\text { plateau age; } 4 \text { of } 8 \\
\text { fractions }\end{array}$ \\
\hline 16AJJ221 & 63.4560 & -141.3952 & $\mathrm{MDg}$ & $\begin{array}{l}\text { muscovite } \\
\text { schist }\end{array}$ & muscovite & 238.1 & 4.4 & $\begin{array}{l}\text { weighted average, } 4 \text { of } \\
8 \text { fractions, criteria not } \\
\text { met for plateau age }\end{array}$ \\
\hline 16AJJ222 & 63.3005 & -141.4890 & Pks & mafic schist & muscovite & 223.8 & 5.4 & $\begin{array}{l}\text { weighted average, } 3 \text { of } \\
8 \text { fractions; criteria not } \\
\text { met for plateau }\end{array}$ \\
\hline 16AJJ272C & 63.4418 & -141.3889 & MDpo & $\begin{array}{l}\text { quartz } \\
\text { muscovite } \\
\text { schist }\end{array}$ & muscovite & 265.7 & 3.2 & $\begin{array}{l}\text { plateau age; } 6 \text { of } 8 \\
\text { fractions }\end{array}$ \\
\hline 17AJJ101 & 63.4616 & -141.5452 & $\mathrm{MDg}$ & $\begin{array}{c}\text { augen } \\
\text { orthogneiss }\end{array}$ & biotite & 92.7 & 2.2 & $\begin{array}{l}\text { plateau age; } 4 \text { of } 8 \\
\text { fractions }\end{array}$ \\
\hline 17AJJ101 & 63.4616 & -141.5452 & MDg & $\begin{array}{c}\text { augen } \\
\text { orthogneiss }\end{array}$ & muscovite & 183.6 & 3.4 & $\begin{array}{l}\text { plateau age; } 3 \text { of } 8 \\
\text { fractions }\end{array}$ \\
\hline 17AJJ104 & 63.2559 & -141.8648 & MDIgs & pelitic schist & muscovite & 99.6 & 1.8 & $\begin{array}{l}\text { plateau age; } 4 \text { of } 8 \\
\text { fractions }\end{array}$ \\
\hline 17AJJ105 & 63.1987 & -141.5678 & MPms & $\begin{array}{c}\text { biotite } \\
\text { orthogneiss }\end{array}$ & muscovite & 193.5 & 6.4 & $\begin{array}{l}\text { weighted average, } 2 \text { of } \\
8 \text { fractions; criteria not } \\
\text { met for plateau }\end{array}$ \\
\hline 17AJJ154 & 63.5159 & -141.4660 & Mems & $\begin{array}{l}\text { quartzose } \\
\text { schist }\end{array}$ & muscovite & 201.4 & 2.2 & $\begin{array}{l}\text { weighted average, } 2 \text { of } \\
8 \text { fractions; criteria not } \\
\text { met for plateau }\end{array}$ \\
\hline 17YTT001 & 63.2963 & -141.7208 & MPms & quartzite & muscovite & 190.7 & 8.0 & $\begin{array}{l}\text { weighted average, } 5 \text { of } \\
8 \text { fractions; criteria not } \\
\text { met for plateau }\end{array}$ \\
\hline 17YTT003 & 63.2361 & -141.4339 & $\mathrm{MDg}$ & orthogneiss & muscovite & 234.7 & 6.0 & $\begin{array}{l}\text { weighted average, } 2 \text { of } \\
8 \text { fractions; criteria not } \\
\text { met for plateau }\end{array}$ \\
\hline 74ASj111 & 63.4833 & -141.1330 & $\mathrm{PEr}$ & Tuff & Sanidine & 57.8 & 3.4 & $\mathrm{~K}-\mathrm{Ar}$ \\
\hline
\end{tabular}


(Wypych and others, 2021; Colpron and others, 2006); however, the trace-element composition of Ladue River unit amphibolites (unit MDa) is similar to that of Fortymile River amphibolites (see chapter C). As discussed in chapter B, metamafic rocks from the Ladue River area have similar plagioclase and hornblende compositions to those of the Fortymile River assemblage, suggesting a similar degree of metamorphism; however, this dataset is not available for the Snowcap assemblage. Key differences between the Ladue River units and the Fortymile River assemblage include: 1) Triassic-Jurassic plutons commonly found in the Fortymile River assemblage are absent in the Ladue River unit, and 2) the Ladue River unit has Late Triassic to Early Jurassic ${ }^{40} \mathrm{Ar} /{ }^{39} \mathrm{Ar}$ cooling ages (table 3; Jones and Benowitz, 2020), whereas Jurassic cooling ages predominate in the Fortymile River assemblage (Naibert and others, 2021) and the Snowcap assemblage (Yukon Geological Survey, 2020). We interpret these data to indicate that the Ladue River unit and Fortymile River assemblage may have shared a common Paleozoic history but became separated during the Mesozoic following peak metamorphism, and hence should be broken out as a separate unit.

MDg METAGRANITOID (EARLY MISSISSIPPIAN-LATE DEVONIAN)—Primarily medium- to coarse-grained orthogneiss of granite or granodiorite composition. Grain size ranges from 0.1 to $15 \mathrm{~mm}$. Unit is variably foliated, but much of unit preserves an equigranular igneous texture and may have only weak foliation in hand sample (fig. 3A). Moderately foliated outcrops have large, equant feldspar porphyroclasts. Unit exhibits amphibolite grade metamorphism and locally has been partially retrograded to greenschist-facies, as evidenced by chloritization of biotite and minor epidote. Mineralogy includes up to 50 percent plagioclase feldspar, 20-80 percent quartz, 20-40 percent alkali-feldspar, 10-55 percent muscovite, 2-40 percent biotite, up to 20 percent chlorite, up to 3 percent epidote, and trace garnet, epidote, titanite, and opaques. Amphibole is observed locally. Unit was most often observed on hilltops and along ridgelines, and shear zones or mylonites were observed at basal contacts, suggesting the unit is in fault contact with the underlying MEms and MDpo units. Magnetic susceptibility ranges from 0.02 to $9.65 \times 10^{-3} \mathrm{SI}$, with an average of $1.08 \times 10^{-3} \mathrm{SI}$ and a median of $0.14 \times 10^{-3} \mathrm{SI}$. U-Pb zircon ages in the map area range from ca. 358 to $376 \mathrm{Ma}$ (Jones and O'Sullivan, 2020; Wildland and others, 2021), suggesting a possible correlation to the Latest Devonian Grass Lakes plutonic suite in Yukon.

MDa AMPHIBOLITE (EARLY MISSISSIPPIAN-LATE DEVONIAN)—An amphibolite facies unit consisting mostly of metamorphosed mafic and lesser intermediate rocks. Fine- to medium-grained, schistose hornblende amphibolite (with partial to extensive greenschist-facies overprint) is the predominant rock type. Mineralogy is 40-60 percent hornblende $(0.3-2 \mathrm{~mm}), 10-20$ percent actinolite (rims and replaces hornblende, $0.2-0.5 \mathrm{~mm}$ ), 0-30 percent plagioclase porphyroblasts $\left(\mathrm{An}_{10-25}\right.$, replaced and (or) or rimmed by albite, $0.5-5 \mathrm{~mm}$ ), 10-30 percent albite (surrounds and replaces plagioclase, $0.5-2 \mathrm{~mm}$ ), $0.5-3$ percent titanite (subhedral, $0.1-0.4 \mathrm{~mm}$ ), $0-0.3$ percent rutile (as inclusions in titanite clusters, $0.05-0.1 \mathrm{~mm}$ ), $1-5$ percent biotite (partly altered to chlorite, $0.02-0.5 \mathrm{~mm}$ ), 3-15 percent chlorite (includes both coarse euhedral and replacement, $0.2-2 \mathrm{~mm}), 3-8$ percent subhedral clinozoisite $(0.3-0.7$ $\mathrm{mm}), 1-3$ percent phengitic muscovite $(0.1-0.4 \mathrm{~mm}), 0.1-0.5$ percent magnetite $(0.05-0.1 \mathrm{~mm})$, and $0-5$ percent quartz $(0.1-0.3 \mathrm{~mm})$. Meta-intermediate rock contains less hornblende and more quartz. Magnetic susceptibility is moderate $\left(0.1-23 \times 10^{-3} \mathrm{SI}\right.$, average $\left.4 \times 10^{-3} \mathrm{SI}\right)$ reflecting variable magnetite content. There is no conclusive evidence that distinguishes between a volcanic or intrusive origin for this unit. A U-Pb zircon age of $361.8 \pm 7.4 \mathrm{Ma}$ from one sample is the basis for the unit age (Wildland and others, 2021). MDa is distinguished from similar-appearing MDla of the Lake George assemblage by virtue of: 1) Absence of calcic plagioclase (see chapter B), garnet, and diopside; B) a more extensive greenschist-facies overprint; and, 3) the presence of clinozoisite instead of epidote and of minor phengitic muscovite. 
MDpo FELDSPAR-PORPHYROCLASTIC ORTHOGNEISS (EARLY MISSISSIPPIAN-LATE DEVONIAN)_Composed primarily of fine- to medium-grained porphyroclastic or porphyroblastic orthogneiss from granodiorite to granite composition (fig. 3B). Porphyroclast-bearing gneisses are interpreted as metamorphosed felsic porphyritic volcanic or shallow intrusive rocks. The orthogneisses form sill-like or sheet-like bodies within unit MPms. Amphibolite- and greenschist-facies mineral assemblages were observed in this unit, without a strong spatial pattern. Chlorite and epidote appear in thin section as rims on biotite and rarely garnet, or as pseudomorphs after those minerals, suggesting the greenschist-facies mineralogy is retrograde alteration of a peak-metamorphic, amphibolite-facies mineral assemblage. Orthogneiss mineralogy includes up to 60 percent plagioclase feldspar, 40-60 percent quartz, up to 45 percent alkali feldspar, 1-25 percent white mica, 1-40 percent biotite, up to 30 percent chlorite, up to 5 percent epidote, and rare garnet. Magnetic susceptibility ranges from 0.02 to $44.82 \times 10^{-3} \mathrm{SI}$, with an average of $1.22 \times 10^{-3} \mathrm{SI}$ and a median of $0.11 \times 10^{-3} \mathrm{SI}$. U-Pb ages in the map area range from ca. 356 to $357 \mathrm{Ma}$ (Jones and O’Sullivan, 2020).

MEms METASEDIMENTARY ROCKS (MISSISSIPPIAN-PROTEROZOIC?)_A composite unit consisting of interlayered paragneiss, quartz schist, semischist, and minor quartzite. Rare, weathered-out calcite-bearing quartzite and semischist was also observed; these were some of the only calcareous rocks in the map area. Sparse orthogneiss layers similar to unit MDpo were noted but were too thin to map. Unit is extensively foliated, as generally defined by micas with variable chloritization. Both amphibolite- and greenschist-facies mineralogy occur throughout the unit; greenschist-facies mineralogy likely represents retrograde conditions following peak metamorphism, as chlorite rims and replaces biotite and garnet. Color ranges from tan to gray to pale green. Grain size ranges from 0.01 to $6 \mathrm{~mm}$ in paragneiss, schist, and quartz schist layers, and up to $15 \mathrm{~mm}$ in quartzite layers. Mineralogy is variable but generally reflects siliciclastic protoliths, including 20 to 95 percent quartz, up to 30 percent albite, up to 60 percent white mica, up to 45 percent chlorite, up to 40 percent biotite, up to 60 percent feldspar, and trace to minor alkali-feldspar, epidote, and garnet. Quartzite and semischist rarely contain small amounts of graphite. Magnetic susceptibility ranges from a minimum of $0.01 \times 10^{-3} \mathrm{SI}$ to an extreme maximum of $26.98 \times 10^{-3} \mathrm{SI}$, with an average of $1.03 \times 10^{-3} \mathrm{SI}$ and a median of $0.12 \times 10^{-3} \mathrm{SI}$. The age of this unit is constrained only by its interlayered relationship with unit MDpo orthogneiss. If that unit has a volcanic protolith then the associated sedimentary rocks were likely deposited during the Late Devonian-Early Mississippian; if MDpo was emplaced as sills, MPms likely comprises the metamorphic equivalents of Neoproterozoic through Devonian Selwyn Basin lithologies.

\section{Parautochthonous rocks of the Jarvis belt}

Rocks of the Jarvis belt are part of pNA but are distinguished from the Lake George assemblage by their younger depositional ages, which are inferred from the presence of interlayered Mississippian-Devonian metavolcanic rocks (MDmr) and a corresponding absence of metaplutonic rocks of that age (MDag). While the Jarvis belt is broadly characterized by greenschist-facies mineralogy (Dashevsky and others, 2003; Sicard and others, 2017), relict hornblende and anorthite-rich plagioclase (see chapter B) indicate these rocks (like those of the Lake George assemblage) reached amphibolite-facies conditions prior to metamorphic cooling in the Early Cretaceous. These rocks are likely correlated with the White River complex in Yukon (Ryan and others, 2013).

kgs GREENSTONE (TRIASSIC?) - Fine-grained $(0.1-1 \mathrm{~mm})$, massive- to weakly foliated greenstone of basaltic composition. Color ranges from pale green to dark gray. Mineralogy is dominated by a retrograde assemblage of actinolite, albite, and epidote-group minerals. Solie and others (2019) identified chlorite and local biotite (possibly pseudomorphic after clinopyroxene) in unit kgs in their map of the adjacent area. Microprobe examination (see chapter B) reveals the presence of relict prograde metamorphic hornblende 
and plagioclase $\left(\mathrm{An}_{23-68}\right)$, and that hornblende and plagioclase locally retain cores of actinolite and albite, respectively, in addition to the retrograde overprint. Magnetic susceptibility ranges from 0.34 to $11.0 \times 10^{-3}$ SI and averages $4.98 \times 10^{-3} \mathrm{SI}$. Age is inferred to be Triassic based on a tentative correlation to dated Triassic metagabbros found in the Jarvis belt and White River Formation regionally (Solie and others, 2014; Murphy and others, 2009; and Ryan and others, 2013; Dashevsky and others, 2003).

MDmr METARHYOLITE (EARLY MISSISSIPPIAN-LATE DEVONIAN)_Weakly foliated, porphyritic metarhyolite with an aphanitic groundmass (fig. 4). Relict phenocrysts include: quartz, 1-2 mm grains, sub-rounded, showing undulose extinction or subgrain formation (5-25 percent); plagioclase, 1-2 mm, subhedral, partially to sericite (5 percent); alkali feldspar, $1-2 \mathrm{~mm}$, and also present locally as augen porphyroclasts up to $10 \mathrm{~mm}$ in diameter $(0-15$ percent); biotite, slightly chloritized to completely replaced by a mixture of oxides and secondary biotite $(0.5-1 \mathrm{~mm}, 0-2$ percent). Some phenocrysts have fragmental shapes suggesting the unit was originally deposited as a tuff. The groundmass comprises a mixture of very fine-grained quartz, white mica, and feldspar; aligned white micas ( -50 micron; 5-20 percent) define a weak metamorphic fabric and an incipient crenulation cleavage in some samples. Other groundmass minerals include trace epidote, chlorite, pyrite, and iron oxide. Magnetic susceptibility ranges from 0.035 to $3.74 \times 10^{-3} \mathrm{SI}$ and averages $0.40 \times 10^{-3} \mathrm{SI}$. Unit has been metamorphosed to amphibolite facies and subsequently retrograded to greenschist facies, based on the local presence of metamorphic biotite (partially replaced by chlorite) and by the presence of hornblende and high-anorthite plagioclase in interlayered metamafic rocks (kgs; samples 19ADW042, 19TJN024; see chapter B). The age of this unit is constrained by a U-Pb zircon age of $366.8 \pm 8.1 \mathrm{Ma}$ (19ET034; Wildland and others, 2021). Unit MDmr metarhyolite is probably the equivalent of "felsic schist and quartzite" (unit Ms) of Solie and others (2019); metarhyolite from that unit yielded a zircon age of 351.7 $\pm 9.3 \mathrm{Ma}$ (Solie and others, 2014).

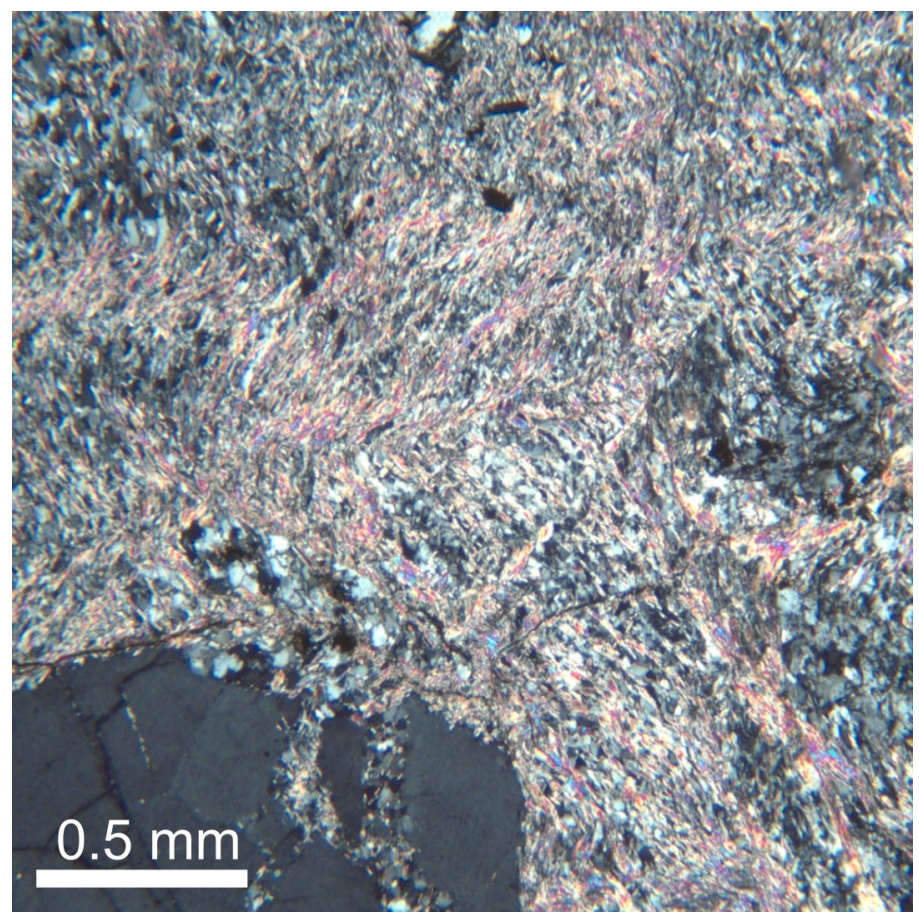

Figure 4. Photomicrograph of unit MDmr showing quartz phenocryst and very fine-grained groundmass with incipient, crenulated metamorphic fabric (sample 19ET034). 
Mcq CHLORITIC QUARTZITE (MISSISSIPPIAN-DEVONIAN)_As described by Solie and others (2019) at the better exposures available outside of our map area, this unit comprises a very-fine- to finegrained, massive to laminated quartzite, in shades of pale to dark greens, grays, and browns, with variable chlorite, biotite, and/or white mica content. Locally contains a few percent of slightly coarser-grained, rounded quartz grains (referred to as grit). Magnetic susceptibility is generally moderately low, averaging $0.72 \times 10^{-3} \mathrm{SI}$, ranging from $0.01 \times 10^{-3}$ to $13.1 \times 10^{-3} \mathrm{SI}$; quartzite with highest values contains magnetite. Mississippian or older age assignment is based on similar metamorphic facies and apparent stratigraphic association with and/or beneath unit Ms (Solie and others, 2019) and MDmr (this map).

\section{Parautochthonous amphibolite-facies metamorphic rocks of Lake George assemblage}

Amphibolite-facies gneiss and schist of the Lake George assemblage occupies the lowest structural level in the map area. The metasedimentary lithologies were deposited prior to the intrusion of Mississippian-Devonian granitic plutons (MDag) and may be the metamorphosed equivalents of the Neoproterozoic-Devonian passive margin strata of the Selwyn Basin. The rocks were metamorphosed to upper amphibolite facies (see chapter B) prior to cooling through ${ }^{40} \mathrm{Ar} /{ }^{39} \mathrm{Ar}$ closure temperatures in the Early Cretaceous (table 3; Pavlis and others, 1993; Dusel-Bacon and others, 2002; Jones and Benowitz, 2020; Naibert and others, 2020)

MDag DIVIDE MOUNTAIN AUGEN GNEISS (EARLY MISSISSIPPIAN-LATE DEVONIAN)_Homogeneous unit of deformed, megacrystic orthogneiss with plutonic protoliths including granite and, locally, granodiorite. This unit is distinguished by its characteristic alkali-feldspar augen porphyroclasts, typically 3 to $8 \mathrm{~mm}$ and locally up to $5 \mathrm{~cm}$ long. Gneissic matrix is fine- to medium-grained, and its mineralogy includes: alkali feldspar, $0.5-3 \mathrm{~mm}$, sub- to anhedral (30-45 percent), typically replaced by sericite; plagioclase, $0.5-3 \mathrm{~mm}$, anhedral (15-20 percent), strong weathering and typically replaced by sericite; quartz, $0.1-0.5 \mathrm{~mm}$, granoblastic (20-45 percent), sweeping and undulatory extinction, irregular grain boundaries and subgrains; biotite, $1-3 \mathrm{~mm}$ long (5-15 percent), defines moderate foliation, varying degrees of chlorite replacement; muscovite, $0.2-0.5 \mathrm{~mm}$ long (3-10 percent), aligned in foliation. The biotite and muscovite often form foliation-parallel, sub-mm bands which separate other felsic layers. Minor minerals include epidote, chlorite, oxides, relict garnets, and zircon. Average magnetic susceptibility is $0.85 \times 10^{-3} \mathrm{SI}$. This unit has a medium- to coarse-grained granitic protolith that is preserved locally; in one outcrop we observed the transition from minimally strained granite into augen orthogneiss dated at $367.6 \pm 8.4$ and $360.7 \pm$ 8.7 Ma, respectively (U-Pb zircon, samples 19SPR174 and 19ADW351C [table 1; Wildland and others, 2021]). Todd and others (2019) obtained a U-Pb zircon age of $355.0 \pm 4.5 \mathrm{Ma}$ from augen orthogneiss in the Divide Mountain area in the Tanacross D-1 Quadrangle. Dusel-Bacon and Williams (2009) reported $\mathrm{U}-\mathrm{Pb}$ zircon ages for four different samples of augen gneiss from this unit outside of our map area, west of Divide Mountain, that yielded ages ranging from $350.4 \pm 5.6 \mathrm{Ma}$ to $370.5 \pm 5.9 \mathrm{Ma}$.

MDIo ORTHOGNEISS (EARLY MISSISSIPPIAN-LATE DEVONIAN)_Fine-grained, weakly to moderately foliated orthogneiss of granodiorite to granite composition, locally mylonitic or schistose. Mineralogy includes: alkali feldspar, $0.5-1 \mathrm{~mm}$ (20-55 percent), often stretched or rotated, twinning common, inclusion-rich, typically replaced by sericite; plagioclase, $0.2-0.5 \mathrm{~mm}$, subhedral (25-40 percent), polysynthetic twinning, sericite replacement common; quartz, $0.2-2 \mathrm{~mm}$ (25-45 percent), undulatory extinction, dynamic recrystallization with subgrains or neograins; biotite, $0.5-2 \mathrm{~mm}$ long (5-15 percent), defining foliation, typically fresh crystals with local chlorite replacement; muscovite, $0.5-2 \mathrm{~mm}$ long (up to 15 percent), defining foliation; and locally, hornblende, subhedral to amorphous clots, aligned in fabric, rims locally show chlorite alteration (5-20 percent). Minor minerals include less than 2 percent garnet, chlorite, 
epidote, pyrite, zircon, apatite. Average magnetic susceptibility is $1.59 \times 10^{-3} \mathrm{SI}$. A leucogranite orthogneiss yielded a U-Pb zircon crystallization age of $370.6 \pm 8.3 \mathrm{Ma}$ (sample 19ADW202; Wildland and others, 2021). In the adjacent Northeast Tanacross geologic map (Wypych and others, 2021), orthogneiss yielded a U-Pb zircon age of $370.6 \pm 9.6 \mathrm{Ma}$ (sample 17JEA001; Todd and others, 2019). This unit correlates to the Lake George orthogneiss (unit MDlo) of Wypych and others (2021) and Solie and others (2019).

MDla AMPHIBOLITE (MISSISSIPPIAN-DEVONIAN)_An amphibolite-facies unit, consisting mostly of metamafic rocks, but also including meta-intermediate and rare meta-ultramafic rocks, that sporadically occurs throughout the Lake George assemblage. Fine- to medium-grained, schistose hornblende amphibolite (commonly with a partial, greenschist-facies overprint) is the predominant rock type. Mineralogy is 50-70 percent hornblende (commonly with actinolite cores and [or] rims, $0.3-2 \mathrm{~mm}$ ), 15-35 percent plagioclase $\left(\mathrm{An}_{25-95}\right.$, but commonly with albite cores and (or) rims; $0.2-1.5 \mathrm{~mm}$; see chapter $\left.\mathrm{B}\right), 0.5-3$ percent titanite (subhedral, $0.1-0.3 \mathrm{~mm}$ ), $0-5$ percent biotite (typically with some alteration to chlorite, 0.02-0.5 mm), 0-5 percent chlorite (includes both subhedral and replacement, $0.2-0.5 \mathrm{~mm}$ ), 0-5 percent subhedral epidote $(0.3-0.7 \mathrm{~mm}), 0.1-1.5$ percent magnetite $(0.05-0.1 \mathrm{~mm}), 0-5$ percent quartz $(0.1-0.3$ $\mathrm{mm}), 0-7$ percent diopside $(0.3-0.5 \mathrm{~mm})$, and $0-5$ percent calcic almandine $(0.5-1 \mathrm{~mm})$. Diopside and garnet-bearing amphibolite is apparently restricted to the northeast part of the map area. Rare meta-ultramafic rock contains $10-40$ percent (retrograde) serpentine and some combination of forsterite-rich olivine, anthophyllite, diopside, tremolite, chlorite, Cr-magnetite, and dolomite (determined by microprobe). Meta-intermediate rock contains more quartz and less amphibole than metamafic rock. Magnetic susceptibility is variable, $0.06-75 \times 10^{-3} \mathrm{SI}$, averaging $3.6 \times 10^{-3} \mathrm{SI}$, reflecting the variable rock types present in the unit. There is no conclusive evidence that distinguishes between a volcanic versus intrusive origin for this unit. The age is constrained by a sample of Lake George amphibolite in the adjacent Northeast Tanacross geologic map dated at $351.5 \pm 4.3 \mathrm{Ma}$ by U-Pb zircon (Wypych and others, 2020).

MDIgs METASEDIMENTARY ROCKS (MISSISSIPPIAN TO PROTEROZOIC)—Composite unit composed of amphibolite-facies paragneiss and interlayered with lesser quartzite, schist, and orthogneiss. Paragneiss is fine- to medium-grained, moderate to strongly foliated, and gneissic to locally schistose. Modal mineralogy includes: quartz, fine-grained, $0.2-2 \mathrm{~mm}$ (40-70 percent), undulatory extinction, irregular grain boundaries, and forms thin sub-mm layers; alkali feldspar, $0.5-2 \mathrm{~mm}$ (20-25 percent), is twinned, forms bands, commonly replaced by sericite; plagioclase, $0.5-1 \mathrm{~mm}$ (10-20 percent), local polysynthetic twinning, weathered; biotite, $0.5-1 \mathrm{~mm}$ (10-30 percent), well-aligned in foliation, fresh looking, forms 1 -mm thick layers; muscovite, very fine-grained (minor, less than 5 percent), found as inclusions in alkali-feldspar observed to be normal to the fabric. The average magnetic susceptibility of the paragneiss is 1.68 x $10^{-3}$ SI. Quartzites are very fine- to fine-grained, locally have lineation defined by muscovite, contain up to 2 percent magnetite and gritty quartz grains. The median magnetic susceptibility of the quartzite is 0.27 $\times 10^{-3} \mathrm{SI}$, but where magnetite is found can be up to $13.8 \times 10^{-3} \mathrm{SI}$. The only age constraint on this unit is that it is the country rock into which Late Devonian to Early Mississippian plutons (unit MDag) intruded; it likely comprises the metamorphic equivalents of Neoproterozoic through Devonian Selwyn Basin lithologies. This unit can be correlated to the Lake George paragneiss (MDlp) of Wypych and others (2021).

MPgq GRITTY QUARTZITE (MISSISSIPPIAN OR OLDER)—As described by Solie and others (2019) in the adjacent map, this unit comprises very-fine- to fine-grained, light- to medium-gray quartzite, characteristically with larger rounded conglomeratic quartz "grit" grains in the finer-grained matrix. White mica \pm biotite content varies; rarely slightly calcareous. Unit also includes minor interlayered white mica-biotite-quartz schist \pm chlorite. Based on fine grain size, common biotite, rare garnet, and relative paucity of chlorite and epidote, unit is interpreted as lower amphibolite facies. Magnetic susceptibility is generally low, averaging $0.11 \times 10^{-3} \mathrm{SI}$, ranging from $0.01 \times 10^{-3}$ to $0.60 \times 10^{-3} \mathrm{SI}$. This unit is the same as unit DEgq of Solie and others (2019). 


\section{ACKNOWLEDGMENTS}

Cynthia Dusel-Bacon and Doug C. Kreiner reviewed the manuscript and provided constructive feedback for which we are most grateful. We also thank J.V. "Jamey” Jones III for ongoing geological discussions and informal reviews.

Donald L. Stevens and David A. Hedderly-Smith shared data and knowledge of the area. Charles G. "Chip" Ireys oriented us to the Moosehorn area, and we also thank him for his hospitality during our three-week stay at his camp. Thanks to Keith Warren and Aurora Aviation for helicopter support, 40-Mile Air for logistical support, and to the Alaska Fire Service for their efforts protecting our camp during the 2019 McArthur Creek fire.

\section{REFERENCES CITED}

AERODAT, 1977, Airborne Electromagnetic Survey Profiles of the Taurus Area: Geophysical survey report to Cities Service Minerals Corporation. (Held by D.L. Stevens, Anchorage, Alaska)

Allan, M.M., Mortensen, J.K., Hart, C.R, Bailey, L.A., Sanchez, M.G., Ciolkiewicz, Wiltold, McKenzie, G.G., and Creaser, R.A., 2013, Magmatic and metallogenic framework of west-central Yukon and eastern Alaska, in Colpron, Maurice, Bissig, Thomas, Rusk, B.G., and Thompson, J.F.H., Tectonics, Metallogeny, and Discovery: The North American Cordillera and Similar Accretionary Settings, Society of Economic Geologists, Special Publication 17, p. 111-168.

Bacon, C.R., Dusel-Bacon, Cynthia, Aleinikoff, J.N., and Slack, J.F., 2014, The Late Cretaceous Middle Fork caldera, its resurgent intrusion, and enduring landscape stability in east-central Alaska: Geosphere, v. 10, p. 1,432-1,455.

Bacon, C.R., Foster, H.L., and Smith, J.G., 1990, Rhyolitic calderas of the Yukon-Tanana terrane, east-central Alaska; Volcanic remnants of a mid-Cretaceous magmatic arc: Journal of Geophysical Research, v. 95, no. B13, p. 21,451-21,461.

Beranek, L.P., and Mortensen, J.K., 2011, The timing and provenance record of the Late Permian Klondike orogeny in northwestern Canada and arc-continent collision along western North
We are grateful to have had access to Doyon Limited lands within the study area, and we thank Doyon Vice President of Lands Jamie Marunde and consulting geologist Harold J. Noyes for their help in securing this permission.

This project was jointly funded by the State of Alaska and the U.S. Geological Survey's Earth Mapping Resources Initiative (Earth MRI) through cooperative agreement G19AC00262. The views and conclusions contained in this document are those of the authors and should not be interpreted as representing the opinions or policies of the U.S. Geological Survey. Mention of trade names or commercial products does not constitute their endorsement by the U.S. Geological Survey.

America: Tectonics, v. 30, no. 5, p. 1-23.

Burns, L.E., Graham, G.R.C., Barefoot, J.D., Naibert, T.J., Fugro Airborne Surveys Corp., and Fugro GeoServices, Inc., 2020a, Ladue electromagnetic and magnetic airborne geophysical survey data compilation: Alaska Division of Geological \& Geophysical Surveys Geophysical Report 2019-20, 15 p. https://doi.org/10.14509/30261

Burns, L.E., Graham, G.E., Emond, A.M., Stevens Exploration Management Corp., and Fugro Airborne Surveys, 2020b, Alaska Highway corridor electromagnetic and magnetic airborne geophysical survey data compilation: Alaska Division of Geological \& Geophysical Surveys Geophysical Report 2020-15, 17 p. https://doi. org/10.14509/30462

Cities Service Minerals Corporation, 1980, Data Compilation, Cities Service Company Prospects, Tanacross Quadrangle, Alaska: Unpublished report, 19 p. (Held by D.L. Stevens, Anchorage, Alaska)

Cockfield, W.E., 1921, Sixtymile and Ladue Rivers area, Yukon: Canada Geological Survey Memoir 123, n. 105, 60 p.

Colpron, Maurice, Nelson, J.L., and Murphy, D.C., 2006, A tectonostratigraphic framework for the pericratonic terranes of the northern $\mathrm{Ca}$ nadian Cordillera, in Colpron, Maurice, and Nelson, J.L., eds., Paleozoic evolution and me- 
tallogeny of pericratonic terranes at the ancient Pacific margin of North America, Canadian and Alaskan Cordillera: Geological Association of Canada Special Paper, v. 45, p. 1-23.

Dashevsky, S.S., Schaefer, C.F., and Hunter, E.N., 2003, Bedrock geologic map of the Delta mineral belt, Tok mining district, Alaska: Alaska Division of Geological \& Geophysical Surveys Professional Report 122, 122 p., 2 sheets, scale 1:63,360. https://doi.org/10.14509/2923

Day, W.C., O'Neill, J.M., Dusel-Bacon, Cynthia, Aleinikoff, J.N., and Siron, C.R., 2014, Geologic map of the Kechumstuk fault zone in the Mount Veta area, Fortymile mining district, east-central Alaska: U.S. Geological Survey Scientific Investigations Map 3291, 1 sheet, scale 1:63,360.

Dilworth, K.M., 2003, Geological setting, nature and evolution of reduced intrusions and gold-bearing quartz veins of the 4021 prospect, Goodpaster district, east-central Alaska: Vancouver, British Columbia, Canada, University of British Columbia, M.S. thesis, 192 p.

Dusel-Bacon, Cynthia, and Aleinikoff, J.N., 1985, Petrology and tectonic significance of augen gneiss from a belt of Mississippian granitoids in the Yukon-Tanana terrane, east-central Alaska: Geological Society of America Bulletin, v. 96, no. 4, p. 411-425.

1996, U-Pb zircon and titanite ages for augen gneiss from the Divide Mountain area, eastern Yukon-Tanana Upland, Alaska, and evidence for the composite nature of the Fiftymile Batholith, in Moore, T.E., and Dumoulin, J.A., eds., Geologic studies in Alaska by the U.S. Geological Survey, 1994: U.S. Geological Survey Bulletin 2152, p. 131-141.

Dusel-Bacon, Cynthia, Aleinikoff, J.N., Day, W.C., and Mortensen, J.K., 2015, Mesozoic magmatism and timing of epigenetic $\mathrm{Pb}-\mathrm{Zn}-\mathrm{Ag}$ mineralization in the western Fortymile mining district, east-central Alaska: Zircon U-Pb geochronology, whole-rock geochemistry, and $\mathrm{Pb}$ isotopes: Geosphere, v. 11, no. 3. https://doi. org/10.1130/GES01092.1

Dusel-Bacon, Cynthia, Day, W.C., and Aleinikoff, J.N., 2013, Geochemistry, petrography, and zir- con U-Pb geochronology of Paleozoic metaigneous rocks in the Mount Veta area of east-central Alaska: implications for the evolution of the westernmost part of the Yukon-Tanana terrane: Canadian Journal of Earth Sciences, v. 50, p. 826-846. Dusel-Bacon, Cynthia, Holm-Denoma, C.S., Jones III, J.V., Aleinikoff, J.N., and Mortensen, J.K., 2017, Detrital zircon geochronology of quartzose metasedimentary rocks from parautochthonous North America, east-central Alaska: Lithosphere, v. 9, no. 6, p. 927-952. https://doi.org/10.1130/ L672.1

Dusel-Bacon, Cynthia, Hopkins, M.J., Mortensen, J.K., Dashevsky, S.S., Bressler, J.R., Day, W.C., 2006, Paleozoic tectonic and metallogenic evolution of the pericratonic rocks of east-central Alaska and adjacent Yukon Territory: Paleozoic Evolution and Metallogeny of Pericratonic Terranes at the Ancient Pacific Margin of North America, Canadian and Alaskan Cordillera, in Colpron, Maurice and Nelson, J.L., eds., Geological Association of Canada Special Paper 45, p. 25-74.

Dusel-Bacon, Cynthia, Lanphere, M.A., Sharp, W.D., Layer, P.W., and Hanson, V.L., 2002, Mesozoic thermal history and timing of structural events for the Yukon-Tanana Upland, east-central Alaska - ${ }^{40} \mathrm{Ar} /{ }^{39} \mathrm{Ar}$ data from metamorphic and plutonic rocks: Canadian Journal of Earth Sciences, v. 39, no. 6, p. 1,013-1,051.

Dusel-Bacon, Cynthia, and Williams, I.S., 2009, Zircon U-Pb evidence for prolonged mid-Paleozoic plutonism and the ages of crustal sources in east-central Alaska: Canadian Journal of Earth Sciences, v. 46, p. 21-39.

Emond, A.M., Saltus, R.W., Graham, Gina, and Goldak Airborne Surveys, 2015, Airborne magnetic geophysical survey of the Tanacross region, Alaska: Alaska Division of Geological \& Geophysical Surveys Geophysical Report 20156. https://doi.org/10.14509/29514

Flanigan, Brian, Freeman, C.J., Newberry, R.J., McCoy, D.T., Hart, C.R., 2000, Exploration models for mid and late Cretaceous intrusion-related gold deposits in Alaska and the Yukon Territory, Canada, in Geology and Ore Deposits 2000: The Great Basin and Beyond, Program 
with Abstracts, Geological Society of Nevada Symposium 2000, Reno, May 2000, p. 47-48.

Foster, H.L., 1967, Geology of the Mount Fairplay area, Alaska: U.S. Geological Survey Bulletin 1241-B, p. B1-B18, 1 sheet, scale 1:63,360.

1970, Reconnaissance geologic map of the Tanacross Quadrangle, Alaska: U.S. Geological Survey Miscellaneous Geologic Investigations Map 593, 1 sheet, scale 1:250,000.

Foster, H.L., Albert, N.R.D., Barnes, D.F., Curtin, G.C., Griscom, Andrew, Singer, D.A., and Smith, J.G., 1976, The Alaskan Mineral Resource Assessment Program; background information to accompany folio of geologic and mineral resource maps of the Tanacross Quadrangle, Alaska: U.S. Geological Survey Circular 734, 19 p.

Foster, H.L., and Igarashi, Yaeko, 1990, Fossil pollen from nonmarine sedimentary rocks of the eastern Yukon-Tanana region, east-central Alaska, in Dover, J.H., and Galloway, J.P., eds., Geologic studies in Alaska by the U.S. Geological Survey, 1989: U.S. Geological Survey Bulletin 1946, p. 11-20.

Foster, H.L., Keith, T.E.C., and Menzie, W.D., 1994, Geology of the Yukon-Tanana area of east-central Alaska, in Plafker, George, and Berg, H.C., eds., The Geology of Alaska: Geological Society of America, p. 205-240.

Gordey, S.P., and Ryan, J.J., 2005, Geology, Stewart River Area (115 N, 115-O and part of 115-J), Yukon Territory: Geological Survey of Canada Open File 4970, 1 sheet, scale 1:250,000.

Hansen, V.L., and Dusel-Bacon, Cynthia, 1998, Structural and kinematic evolution of the $\mathrm{Yu}$ kon-Tanana Upland tectonites, east-central Alaska-A record of late Paleozoic to Mesozoic crustal assembly: Geological Society of America Bulletin v. 110, no. 2, p. 211-230.

Hansen, V.L., Heizler, M.T., and Harrison, T.M., 1991, Mesozoic thermal evolution of the YukonTanana composite terrane; new evidence from ${ }^{40} \mathrm{Ar} /{ }^{39} \mathrm{Ar}$ data: Tectonics, v. 10 , no. 1 , p. 51-76. Hart, C.J.R., Goldfarb, R.J., Lewis, L.L., and Mair, J.L., 2004, The Northern Cordilleran Mid-Cretaceous Plutonic Province: Ilmenite/ Magnetite-series Granitoids and Intrusion-related Mineralisation: Resource Geology, v. 54, no.
3, p. 253-280.

Jones III, J.V., and Benowitz, J.A., 2020, ${ }^{40} \mathrm{Ar} /{ }^{39} \mathrm{Ar}$ isotopic data and ages for rocks from the Yukon-Tanana upland of eastern Alaska and the northern Aleutian Range of south-central Alaska: U.S. Geological Survey data release. https://doi.org/10.5066/P96762V3

Jones III, J.V., and O'Sullivan, Paul, 2020, U-Pb isotopic data and ages of zircon, titanite, and detrital zircon from rocks from the Yukon-Tanana Upland, Alaska: U.S. Geological Survey data release. https://doi.org/10.5066/P9WWV93S

Jones III, J.V., Todd, Erin, Caine, J.S., Holm-Denoma, C.S., Ryan, J.J., and Benowitz, J.A., 2017, Late Permian (ca. 267-257 Ma) magmatism, deformation, and metamorphism and lithotectonic associations of the Ladue River unit in east-central Alaska [abs.]: Geological Society of America Abstracts with Programs, v. 49, no. 6. https://doi.org/10.1130/abs/2017AM-304170

Joyce, N.L., 2002, Geologic setting, nature, and structural evolution of intrusion-hosted Au-bearing quartz veins at the Longline occurrence, Moosehorn Range area, west-central Yukon Territory: Vancouver, Canada, University of British Columbia, unpublished Master's thesis, 199 p.

Keith, T.E.C., Foster, H.L., Foster, R.L., Post, E.V., and Lehmbeck, W.L., 1981, Geology of an alpine-type peridotite in the Mount Sorenson area, east-central Alaska: U.S. Geological Survey Professional Paper 1170-A, p. A1-A9.

Kennecott Exploration, 2019, Oreo Mountain Project Handover Memo: Unpublished report to Tubutulik Mining Company, 11 p. (Held by D.A. Hedderly-Smith, Poulsbo, Washington)

Kerin, L.J., 1976, The reconnaissance petrology of the Mt. Fairplay igneous complex: Fairbanks, Alaska, University of Alaska Fairbanks, M.S. thesis, 95 p., 5 plates, 4 sheets.

Kreiner, D.C., Jones III, J.V., Todd, Erin, Holm-Denoma, Chris, Caine, J.S., Benowitz, J.A., 2019, Links between tectonics, magmatism, and mineralization in the formation of Late Cretaceous porphyry systems in the Yukon-Tanana upland, eastern Alaska, USA: Proceedings of the 15th biennial meeting for geology applied to mineral deposits, p. 939-942. 
Lowey, G.V., and Hills, L.V., 1988, Lithofacies, petrography and environments of deposition, Tantalus Formation (Lower Cretaceous) Indian River area, West-Central Yukon, Bulletin of Canadian Petroleum Geology, v. 36, p. 296-310.

Mair, J.L., Hart, C.J.R., Stephens, J.R., 2006, Deformation history of the northwestern Selwyn Basin, Yukon, Canada: Implications for orogen evolution and mid-Cretaceous magmatism: Geological Society of America Bulletin, v. 118, p. 304-323.

Milidragovic, Dejan, Ryan, J.J., Zagorevski, Alexandre, Piercey, S.J., 2016, Geochemistry of Permian rocks of the Yukon-Tanana terrane, western Yukon: GEMS 2 Cordillera project: Geological Survey of Canada Open File 8170, 21 p.

Murphy, D.C., Mortenson, J.K., Piercey, S.J., Orchard, M.J., and Gehrels, G.E., 2006, Mid-Paleozoic to early Mesozoic tectonostratigraphic evolution of Yukon-Tanana and Slide Mountain terranes and affiliated overlap assemblages, Finlayson Lake massive sulphide district, southeastern Yukon: Paleozoic Evolution and Metallogeny of Pericratonic Terranes at the Ancient Pacific Margin of North America, Canadian and Alaskan Cordillera, in Colpron, Maurice and Nelson, J.L., eds., Geological Association of Canada Special Paper 45, p. 75-105.

Murphy, D.C., Mortensen, J.K., and van Staal, Cees, 2009, 'Windy-McKinley' terrane, western Yukon-New data bearing on its composition, age, correlation and paleotectonic settings, in Weston, L.H., Blackburn, L.R., and Lewis, L.L., eds., Yukon Exploration and Geology 2008: Yukon Geological Survey, p. 195-209.

Naibert, T.J., Benowitz, J.A., Wypych, Alicja, Sicard, K.R., and Twelker, Evan, 2018, ${ }^{40} \mathrm{Ar} /{ }^{39} \mathrm{Ar}$ data from the Tanacross D-1 and D-2, Big Delta B-4 and B-5, and Mount Hayes A-6 quadrangles, Alaska: Alaska Division of Geological \& Geophysical Surveys Raw Data File 2018-3, 15 p. https://doi.org/10.14509/30112

2020, ${ }^{40} \mathrm{Ar} /{ }^{39} \mathrm{Ar}$ data from the Tanacross D-1 and parts of the D-2, C-1, and C-2 quadrangles, Alaska: Alaska Division of Geological \& Geophysical Surveys Raw Data File 2020-12, 35 p. https://doi.org/10.14509/30466

Naibert, T.J., Wypych, Alicja, Twelker, Evan, and Benowitz, J.A., 2021, Metamorphic cooling history of the Fortymile River and Lake George assemblages from ${ }^{40} \mathrm{Ar} /{ }^{39} \mathrm{Ar}$ geochronology from the northeast Tanacross and southeast Eagle quadrangles, Alaska, in Wypych, Alicja, Northeast Tanacross geologic mapping project, Alaska: Alaska Division of Geological \& Geophysical Surveys Report of Investigation 2020-9C. https://doi.org/10.14509/30540

Nelson, J.L., Colpron, Maurice, Piercey, S.J., Dusel-Bacon, Cynthia, Murphy, D.C., and Roots, C.F., 2006, Paleozoic tectonic and metallogenetic evolution of pericratonic terranes in Yukon, northern British Columbia and eastern Alaska: Paleozoic Evolution and Metallogeny of Pericratonic Terranes at the Ancient Pacific Margin of North America, Canadian and Alaskan Cordillera, in Colpron, Maurice and Nelson, J.L., eds., Geological Association of Canada Special Paper 45, p. 323-360.

Newberry, R.J., 2020, The Mount Fairplay igneous complex: Alaska Division of Geological \& Geophysical Surveys Preliminary Interpretive Report 2020-1, 32 p. https://doi.org/10.14509/30463

Newberry, R.J., Bundtzen, T.K., Clautice, K.H., Combellick, R.A., Douglas, Tom, Laird, G.M., Liss, S.A., Pinney, D.S., Reifenstuhl, R.R., and Solie, D.N., 1996, Preliminary geologic map of the Fairbanks mining district, Alaska: Alaska Division of Geological \& Geophysical Surveys Public Data File 96-16, 17 p., 2 sheets, scale 1:63,360. https://doi.org/10.14509/1740

Nokleberg, W.J., and Aleinikoff, J.N., 1985, Summary of stratigraphy, structure, and metamorphism of Devonian igneous-arc terranes, northeastern Mount Hayes quadrangle, eastern Alaskan Range, in Bartsch-Winkler, Susan, ed., The United States Geological Survey in Alaska; accomplishments during 1984: U.S. Geological Survey Circular 967, p. 66-70.

Parsons, A.J., Coleman, M.J., Ryan, J.J., Zagorevski, Alexandre, Joyce, N.L., Gibson, H.D., Larson, K.P., 2018, Structural evolution of a crustal-scale shear zone through a decreasing 
temperature regime: The Yukon River shear zone, Yukon-Tanana terrane, Northern Cordillera: Lithosphere v. 10, p. 760-782. https://doi. org/10.1130/L724.1

Pavlis, T.L., Sisson, V.B., Foster, H.L., Nokleberg, W.J., and Plafker, George, 1993, Mid-Cretaceous extensional tectonics of the Yukon-Tanana Terrane, Trans-Alaska Crustal Transect (TACT), east-central Alaska: Tectonics, v. 12, p. 103-122. https://doi.org/10.1029/92TC00860

Piercey, S.J., and Colpron, Maurice, 2009, Composition and provenance of the Snowcap assemblage, basement to the Yukon-Tanana terrane, northern Cordillera: Implications for Cordilleran crustal growth: Geosphere, v. 5, p. 439-464. https://doi.org/10.1130/ges00505.1

Piercey, S.J., Nelson, J.L., Colpron, Maurice, Dusel-Bacon, Cynthia, Simard, R.-L. and Roots, C.F., 2006, Paleozoic magmatism and crustal recycling along the ancient Pacific margin of North America, northern Cordillera: Paleozoic Evolution and Metallogeny of Pericratonic Terranes at the Ancient Pacific Margin of North America, Canadian and Alaskan Cordillera, Colpron, in Maurice and Nelson, J.L., eds., Geological Association of Canada Special Paper 45, p. 323-360.

Ryan, J.J., Zagorevsky, Alexandre, Roots, C.F., and Joyce, N.L., 2014, Paleozoic tectonostratigraphy of the northern Stevenson Ridge area, Yukon: Geological Survey of Canada, Current Research 2014-4, 13 p. https://doi.org/10.4095/293924

Ryan, J.J., Zagorevski, Alexandre, Williams, S.P., Roots, C.F., Cioliewicz, W., Hayward, N., and Chapman, J.B., 2013, Geology, Stevenson Ridge (northwest part), Yukon: Geological Survey of Canada, Canadian Geoscience Map 117 (2nd edition, preliminary), scale 1:100,000. http:// doi.org/10.4095/292408

Sánchez, M.G., Allan, M.M., Hart, C.J., Mortensen, J.K., 2014, Extracting ore-deposit-controlling structures from aeromagnetic, gravimetric, topographic, and regional geologic data in western Yukon and eastern Alaska: Interpretation, v. 2, no. 4, p. SJ75-SJ 102.

Sicard, K.R., Naibert, T.J., Hubbard, T.D., Twelker, Evan, Wypych, Alicja, Werdon, M.B., Will- ingham, A.L., Gillis, R.J., Lande, L.L., and Newberry, R.J., 2017, Geologic map of the Tok River area, Tanacross A-5 and A-6 quadrangles, eastern Alaska Range, Alaska: Alaska Division of Geological \& Geophysical Surveys Preliminary Interpretive Report 2017-3, 15 p., 1 sheet, scale 1:63,360. https://doi.org/10.14509/29722

Solie, D.N., Layer, P.W., Werdon, M.B., Newberry, R.J., Freeman, L.K., and Lessard, R.R., 2013, ${ }^{40} \mathrm{Ar} /{ }^{39} \mathrm{Ar}$ data, Alaska Highway corridor from Delta Junction to Canada border, parts of Mount Hayes, Tanacross, and Nabesna quadrangles, Alaska: Alaska Division of Geological \& Geophysical Surveys Raw Data File 2013-8, 35 p. https://doi.org/10.14509/26841

Solie, D.N., O’Sullivan, P.B., Werdon, M.B., Freeman, L.K., Newberry, R.J., Szumigala, D.J., and Hubbard, T.D., 2014, Zircon U-Pb age data, Alaska Highway Corridor, Tanacross and Nabesna quadrangles, Alaska: Alaska Division of Geological \& Geophysical Surveys Raw Data File 2014-16, 29 p. https://doi.org/10.14509/27322 Solie, D.N., Werdon, M.B., Freeman, L.K., Newberry, R.J., Szumigala, D.J., Speeter, G.G., and Elliott, B.A., 2019, Bedrock-geologic map, Alaska Highway corridor, Tetlin Junction, Alaska to Canada border: Alaska Division of Geological \& Geophysical Surveys Preliminary Interpretive Report 2019-3, 16 p., 2 sheets, scale 1:63,360. https://doi.org/10.14509/30038

Szumigala, D.J., Newberry, R.J., Werdon, M.B., Athey, J.E., Flynn, R.L., and Clautice, K.H., 2002, Bedrock geologic map of the Eagle A-1 Quadrangle, Fortymile mining district: Alaska Division of Geological \& Geophysical Surveys Preliminary Interpretive Report 2002-1B, 1 sheet, scale 1:63,360. https://doi. org/10.14509/2864

Todd, Erin, Wypych, Alicja, and Kylander-Clark, Andrew, 2019, U-Pb and Lu-Hf isotope, age, and trace element data from zircon separates from the Tanacross D-1, and parts of D-2, C-1, and C-2 quadrangles: Alaska Division of Geological \& Geophysical Surveys Raw Data File 2019-5, 10 p. https://doi.org/10.14509/30198

Twelker, Evan, and O'Sullivan, P.B., 2021a, U-Pb 
zircon data and ages for bedrock samples from the Richardson mining district, Big Delta Quadrangle, Alaska: Alaska Division of Geological \& Geophysical Surveys Raw Data File 2020-14, 17 p. https://doi.org/10.14509/30555

2021b, U-Pb detrital zircon geochronology of Cretaceous-Cenozoic sedimentary rocks in the Ladue River-Mount Fairplay area, Alaska: Alaska Division of Geological \& Geophysical Surveys Preliminary Interpretive Report 2021-2, 16 p. https://doi.org/10.14509/30683

Wahrhaftig, Clyde, 1960, The physiographic provinces of Alaska: U.S. Geological Survey OpenFile Report 60-146, 76 p.

Werdon, M.B., Newberry, R.J., and Szumigala, D.J., 2001, Bedrock geologic map of the Eagle A-2 Quadrangle, Fortymile mining district, Alaska: Alaska Division of Geological \& Geophysical Surveys Preliminary Interpretive Report 2001-3B, 1 sheet, scale 1:63,360. https://doi. org/10.14509/2670

Wildland, A.D., Wypych, Alicja, Regan, S.P., and Holland, Mark, 2021, U-Pb zircon ages from bedrock samples collected in the Tanacross and Nabesna quadrangles, eastern Alaska: Alaska Division of Geological \& Geophysical Surveys Preliminary Interpretive Report 2021-4, 47 p. https://doi.org/10.14509/30732

Wilson, F.H., Hults, C.P., Mull, C.G., and Karl, S.M., 2015, Geologic map of Alaska: U.S. Geological Survey Scientific Investigations Map 3340, 196 p., 2 sheets, scale 1:1,584,000. https://alaska.usgs.gov/science/geology/state_ map/interactive_map/AKgeologic_map.html
Wypych, Alicja, Hubbard, T.D., Naibert, T.J., Athey, J.E., Newberry, R.J., Sicard, K.R., Twelker, Evan, Werdon, M.B., Willingham, A.L., Wyatt, W.C., and Lockett, A.C., 2021, Northeast Tanacross geologic map and map units and descriptions, in Wypych, Alicja, ed., Northeast Tanacross geologic mapping project, Alaska: Alaska Division of Geological \& Geophysical Surveys Report of Investigation 2020-9B. https://doi.org/10.14509/30539

Wypych, Alicja, Jones, J.V., III, and O'Sullivan, Paul, 2020, U-Pb zircon ages from bedrock samples collected in the Tanacross D-1, and parts of the D-2, C-1, and C-2 quadrangles, Alaska: Alaska Division of Geological \& Geophysical Surveys Preliminary Interpretive Report 2020-2, 19 p. https://doi.org/10.14509/30465

Wypych, Alicja, Twelker, Evan, Naibert, T.J., Athey, J.E., Newberry, R.J., Lopez, J.A., Regan, S.P., Sicard, K.R., Wildland, A.D., and Wyatt, W.C., 2019, Major-oxide and trace-element geochemical data from rocks collected in 2019 for the Eastern Tanacross project, Tanacross and part of Nabesna quadrangles, Alaska: Alaska Division of Geological \& Geophysical Surveys Raw Data File 2019-8, 3 p. https://doi. org/10.14509/30267

Yukon Geological Survey, 2019, Yukon Digital Bedrock Geology. www.geology.gov.yk.ca/update_yukon_bedrock_geology_map.html [accessed: 3/19/2019]

2020, Yukon Geochronology - A database of Yukon isotopic age determinations: Yukon Geological Survey.http://data.geology.gov.yk.ca/ Compilation/22 [accessed February 1, 2021] 